\title{
Renewable energy sources: Their global potential for the first-half of the 21st century at a global level: An integrated approach
}

\author{
Bert J.M. de Vries ${ }^{\mathrm{a}, *}$, Detlef P. van Vuuren ${ }^{\mathrm{b}}$, Monique M. Hoogwijk ${ }^{\mathrm{a}}$ \\ ${ }^{\mathrm{a}}$ Netherlands Bureau of Environmental Assessment (MNP), P.O. Box 303, Bilthoven, The Netherlands \\ ${ }^{\mathrm{b}}$ Ecofys, P.O. Box 8408, Utrecht, The Netherlands \\ Received 11 April 2006; accepted 4 September 2006 \\ Available online 15 November 2006
}

\begin{abstract}
The risk of human-induced climate change and the volatility of world oil markets make non-fossil fuel options important. This paper investigates the potential for wind, solar-PV and biomass (WSB) to deliver energy. The focus is on land opportunities and constraints and on production costs as a function of resource availability and depletion and of innovation dynamics. The context is provided by the IPCC SRES scenarios as simulated with the IMAGE 2.2 model. We explicitly consider several sources of uncertainty, aspects of the food vs. energy trade-off and the effects of interaction between the three options through their claims on land. We show that "potential production' concepts are strongly dependent on the chosen land-use scenario - and should therefore be used with an indication of the underlying assumptions. Our results indicate a potential for liquid biofuels in the order of 75-300 EJ year ${ }^{-1}$ and for electricity from WSB options at production costs below $10 \varnothing \mathrm{kWh}^{-1}$ of 200-300 $\mathrm{PWh}_{\text {year }}{ }^{-1}$. Theoretically, future electricity demand can be amply met from WSB sources in most regions by 2050 below $10 \propto \mathrm{kWh}^{-1}$, but major uncertainties are the degree to which land is actually available and the rate and extent at which specific investment costs can be reduced. In some regions, competition for land among the three WSB options may significantly reduce the total potential as estimated from simple addition — which is another source of uncertainty.
\end{abstract}

(C) 2006 Elsevier Ltd. All rights reserved.

Keywords: Renewable energy; Techno-economic potential; Economic potential; Scenario analysis

\section{Introduction}

Decision-makers, societal groups and scientists have at various moments in time expressed their interest in renewable energy sources such as power from wind, sun and biomass-derived fuels. Recently, this interest has been on the rise again. Several reasons are mentioned for this: the risk of energy supply insecurity and the corresponding need for resource diversification, the prospect of depletion and hence cost increases of conventional oil and gas occurrences and the adverse impacts of climate change and local air pollution ${ }^{1}$ as a result of fossil-fuel burning related emissions. The concerns show up in questions asked by policy makers, citizen groups and industrial firms: How

\footnotetext{
*Corresponding author. Tel.: + 31302743533.

E-mail address: bert.de.vries@mnp.nl (B.J.M. de Vries).

${ }^{1}$ A comparative environmental advantage does not necessarily apply for biomass applications.
}

fast can renewable energy sources expand? When will they be competitive with conventional energy options? Which role can they play in reducing greenhouse gas emissions and which are the best policy instruments to stimulate their introduction? To answer such questions adequately, it is necessary to have proper insight in the potential availability of renewable energy sources at different costs levels, and also in the evolution of the energy system in which these resources have to be implemented.

The potential availability of wind, solar and biomass energy varies over time and between locations. This variation is not only caused by the resource characteristics (wind/solar regime, soil) but also by geographical (land use and land cover), techno-economic (scale, labour cost) and institutional (policy regime, legislation) factors. Some of these factors cannot or can only approximately be quantified. As a consequence, an assessment of the longterm role of renewable energy sources has to rely on a combination of data from observations, mathematical 
models and narratives - that is, on scenarios (De Vries, 2006). In the past, several estimates of the worldwide potential of renewable energy options have been made, for instance for wind energy (Grubb and Meyer, 1993; World Energy Council (WEC), 1994; Fellows, 2000; Rogner, 2000; Sørensen, 2000), solar energy (Rogner, 2000; Sørensen, 2000; Hofman et al., 2002) and biomass energy (Rogner, 2000; Berndes et al., 2003). These studies mostly focus on one specific source only or, when including several sources, lack a well-defined generic approach. They also use different regional aggregation. Also, most studies concentrate on 'technical potentials' and do not consider the economic potential. Besides, the underlying assumptions are often not clearly stated. All these factors make a comparison of various analyses across regions and resources quite complicated. A clear description of the calculation procedure and assumptions is therefore crucial to reach more consensus on the renewable resource potential.

In this paper, we present a new assessment of future costs and technical potential of electricity from onshore wind, solar-PV and modern biomass in centralized generation units and fuel from biomass (abbreviated to WSB), using a generic and integrated approach across the different resources. ${ }^{2}$ It permits an integrated, comparative analysis of the three WSB-options and of the role of uncertainties, in particular land availability and technology. An additional reason to provide new estimates of the potential of renewable energy options is the availability of better data on resource characteristics and technological and economic performances and prospects. Hydropower, geothermal power, tidal power and other techniques to capture solar energy directly have significant potential in some regions, but are not considered in this paper.

We use worldwide geographical data on wind speed, solar radiation and biomass yields. These are combined with estimates of constraints on land availability and on existing and future costs. The resulting regional cost-supply curves for different scenarios and for the period 2000-2050 are compared with projected energy demand and with other estimates found in the literature. The possible interference between wind, solar-PV and biomass are explored in order to find the interesting high-potential locations.

\section{Renewable energy potentials: definition and methodology}

\subsection{Definitions}

We distinguish the following definitions for renewable energy potentials, based on the World Energy Council

\footnotetext{
${ }^{2}$ The method applied for each individual electricity resource has been published earlier in individual papers (Hoogwijk et al., 2005, 2004; Hoogwijk, 2004)
}

Report (WEC, 1994; Hoogwijk, 2004)33:

- The geographical potential is the energy flux theoretically extractable in areas that are considered suitable and available for this production i.e. in areas which are not excluded by other incompatible land cover/use and/or by constraints set on local characteristics such as elevation and minimum average wind speed;

- The technical potential is the geographical potential after the losses of the conversion from the extractable primary energy flux to secondary energy carriers or forms (electricity, fuel) are taken into account; and

- The economic potential is the technical potential up to an estimated production cost of the secondary energy form which is competitive with a specified, locally relevant alternative. A flexible way to represent the economic potential is in the form of the energy production potential as function of the production cost, the socalled long-run supply cost curve (LSCC).

While the potentials are often presented as 'objective', most of them are strongly influenced by assumptions on average values and trends. The geographical potential contains by its very definition a number of assumptions on land suitability and resource availability. Some of these are, within the time period concerned, given - such as wind speed and solar radiation regime and soil characteristics. ${ }^{4}$ Other assumptions are more of a socio-cultural or politicoeconomic nature - such as land availability and the need for agricultural land to produce food. The technical potential is derived from the geographical potential and assumptions on the development of conversion efficiencies. For instance, for solar-PV electricity, assumptions need to be made on how conversion efficiency may develop from around $10 \%$ today to potentially much higher efficiencies in the future. Finally, for the economic potential it is necessary to estimate the average cost at which the secondary energy carrier (electricity, fuel) can be produced at a given locality. This depends on a variety of mostly techno-economic factors such as investment costs of available technology, labour wages and skills, and interest rates.

Whether a potential is realized and how fast - the implementation potential for any given year-depends on many of the assumptions underlying the geographical as well as the technical and economic potential calculations. Moreover, policies and preferences in society (subsidies, feed-in tariffs and other policy incentives), perceived urgency of issues such as climate change or import dependence and the like will all play a role in this respect. There may be some confusion as to the difference between

\footnotetext{
${ }^{3}$ The theoretical potential is the energy flux theoretically extractable from the renewable resource; it is rather arbitrary and has not much practical value so we leave it out here;

${ }^{4}$ See for the possible change in wind speed due to climate change (Alcamo et al., 2002).
} 
economic and implementation potential. What we calculate as economic potential is the potential production of WSBbased energy at a given production cost. The implementation potential not only depends on these production costs, but also on system factors such as the production costs of alternative options to produce fuel, specific implementation barriers such as availability of knowledge and the costs of integrating WSB energy into the larger energy system. ${ }^{5}$ Despite clear definitions, the estimates of these potentials, and in particular of the geographical and implementation potential, require a set of context related additional assumptions. As we will show further in this article, coupling potentials to scenarios is one way of making these additional assumptions transparent.

\subsection{Generic procedure to assess renewable resource potentials}

The assessment methodology of a renewable energy potential can be formulated in a rather universal way. First, the relevant physical and geographical data for the regions considered are collected on a sufficiently high resolution. We use the soil and land-use land-cover data from the IMAGE 2.2 model, available at grid cell level $\left(0.5^{\circ} \times 0.5^{\circ}\right)$. The wind and solar characteristics are from the digital database at the same resolution constructed by the climate research unit (CRU) and adjusted to the coordinates of the IMAGE-grid (New et al., 1997, 1999). ${ }^{6}$ This resolution is still too coarse for local assessments but has the advantage of global coverage.

First, an assessment is made of which part of the area considered can be used for energy production given the physical-geographical characteristics, that is, of the average suitability/availability. This yields the geographical potential, which has for a geographical unit (grid-cell) $i$ with an area surface $A_{i}$ (in $\mathrm{m}^{2}$ ) the general form:

$E G_{i}=f_{i} A_{i} E_{i} \quad(\mathrm{~W})$

with $E_{i}$ the theoretically extractable energy output per unit surface area (in $\mathrm{W} \mathrm{m}^{-2}$ ).

The suitability/availability factor $f_{i}$ typically depends on physical-geographical factors (terrain, habitation) but also on socio-geographical parameters (location, acceptability). The theoretically available primary energy $E_{i}$ can only partly be extracted in the form of useful secondary energy carriers. This is accounted for in the expression for the

\footnotetext{
${ }^{5}$ These broader system considerations will be included in subsequent analyses with the energy model TIMER 2.0 and the land use land cover submodel of IMAGE 2.2 (see Hoogwijk et al., 2006).

${ }^{6}$ The geographical co-ordinates of the CRU-data do not match completely with the grid cell definition of the IMAGE 2.2 database. The CRU database has been converted to the raster of the IMAGE 2.2 database from which all the land-use data are taken. There are also differences in the definition of land cells versus sea cells. This was the case for 4200 (border) grid cells. These data have been converted by means of linear interpolation. Cells that border the shore are included in this study if more than $10 \%$ is defined as land. We have included only the onshore area fraction in these cells.
}

technical potential $E T_{i}$ :

$E T_{i}=f_{i} A_{i} \Phi\left[\eta_{i}, D_{i}, \lambda_{i}\right] E_{i} \quad(\mathrm{~W})$

with $\Phi$ a function of the over-all conversion efficiency $\eta_{i}$, which depends on technology characteristics, and of the power density $D_{i}$. The latter represents constraints posed by technical factors such as turbine interference or biomass yields for the area $f_{i} A_{i}$ under consideration, but also by social constraints such as the preference for dense or less dense wind parks and the associated visual impact. The parameter $\lambda_{i}$ represents an aggregate of other parameters such as operational details. A next and final step is to relate this technical potential to the on-site production energy carrier costs. This results in the economic potential $E E_{i c}$ :

$E E_{i c}=E T_{i} \Psi\left[c, S_{i}, C P_{i}, \mu\right] \quad(\mathrm{W})$

with $c$ cut-off cost, that is, the maximum cost level considered. $\Psi$ is a function converting technical to economic output. It contains two factors which are assumed to influence production costs: the conversion equipment scale, $S_{i}$, and the cumulated output for the area, $C P_{i}$. These two parameters take into account economiesof-scale (upscaling and series production) and learning-bydoing which both tend to lead to lower specific investment costs (see e.g. Junginger et al., 2005). The parameter $\mu$ consists of operational parameters which in this analysis are all considered to be site independent, as will be discussed later on.

To get the regional potential in energy units per year, one has to convert to GJ unit ${ }^{-1}$ year $^{-1}$ or $_{\mathrm{kWh}}$ unit $^{-1}$ year $^{-1}$ assuming that all energy flow densities are annual averages, and then sum over all the geographical units (grid-cells) in the particular region. Summing up over all regions gives the worldwide (or global) technical potential. Arranging the outcome across the grid-cells in order of ascending costs yields the regional and global LSCC and, for any cutoff costs $c$, the regional and global economic potential. We now proceed with the application of this generic approach to the three renewable sources: first biomass, then wind and solar-PV. The basic equations are given in Appendix A and a quantification of the assumptions is given in Appendix B.

\subsection{Liquid transport fuel and electricity from biomass}

Out of the many possible conversion routes from primary biomass to commercial energy carriers, we have selected only two:

- liquid biofuel (ethanol and Fisher-Tropsch diesel) for which we assume that it can be produced from three different crop categories: woody biomass (grown in short rotations), maize and sugar cane; and

- electricity, for which we consider woody biomass only.

Together, these categories give a reasonable representation of the potential biomass production in a region given grid cell level information on temperature, soil and 
precipitation. Other considerations are that there is plentiful information on all these three categories and that they, and in particular woody biomass, can be converted into all types of secondary energy carriers. ${ }^{7}$ For temperate climates a typical crop is probably willow or poplar, whereas eucalyptus is often the most suitable perennial woody biomass crop in more tropical climates. However, the species of energy crop is not specified further because, among other reasons, in the IMAGE 2.2 model the productivity of energy crops is parameterised in a generic way by assuming optimal photosynthesis efficiency (e.g. optimal water use efficiency) at grid cell level.

To estimate the parameters for the geographic potential of biomass from energy crops, we have used the IMAGE 2.2 implementation of the IPCC SRES-scenarios (IMAGEteam, 2001; Strengers et al., 2004) as the basis for evaluating the amount and quality of land which could become available for biomass-derived energy-hence, our potentials are scenario-based upper limits. The scenarios will be discussed in more detail in the next section. The important step is to decide which of the various land categories $\left(A_{i}\right)$ are available for energy crops and to which extent $\left(f_{i}\right)$. We use the IMAGE-based estimates of the average productivity $Y_{i}$ in any grid-cell I and given year to choose areas to be considered: cropland is not available, forest lands are to be preserved and low-productivity land will not yield competitively priced biomass. ${ }^{8}$ Hence, the categories abandoned cropland and rest land are the interesting ones. ${ }^{9}$ The exogenously set management factor is assumed to increase over time (cf. Section 3.3). Besides the differences in land availability, this is the other major reason why the calculated biomass potentials will differ for the scenarios. Given these assumption, we calculate the scenario-dependent potential for primary biomass.

The next step is to estimate the economic potential in the form of an LSCC. The cost of primary biomass is based upon an estimate of both capital and labour costs, with a cost reduction from learning-by-doing in both capital and labour (factorneutral). The ratio $K / L$ is made dependent on the relative cost ratio (wages $w$ /interest rate $r$ ) according to a Cobb-Douglas production function to take into account that labour will be substituted for capital if wages rise. Primary biomass is converted into liquid biofuel or feedstock for electricity production, using crop-specific conversion efficiency and capital requirements based on Damen and Faaij (2004), Hamelinck (2004) and Hendriks

\footnotetext{
${ }^{7}$ The fact that non-woody, $\mathrm{C} 4$ grasses have not been included causes an underestimation of the potential in the tropical regions where higher productivity levels can be expected when herbaceous crops are used (Hall et al., 1993).

${ }^{8}$ For the definitions of crop productivity as used in the IMAGE-model, see Alcamo et al. (1998) and Hoogwijk et al. (2005).

${ }^{9}$ Restland here is the leftover of the other categories (cropland, abandoned cropland, bioreserves, forest and lowproductivity lands) corrected for grassland, forest land, urban area and bioreserves and includes mainly savannah, shrubland and grassland/steppe. Tundra area is excluded as it is considered to be unsuitable for energy crop production.
}

et al. (2004). In the case of biofuels, in each grid-cell the crop with the lowest production costs is chosen from the three different feedstock crops. If the biomass is used to generate electricity, two different dedicated power plant types are considered (conventional and gasification) and in each grid-cell the plant type with the lowest costs is chosen. Until 2030 the conventional plant is generally the cheaper option; after 2030-2050 the gasification plant is (cf. Section 3.3).

\subsection{Electricity from on-shore wind}

The resource data are monthly wind speed data in $\mathrm{m} \mathrm{s}^{-1}$ at a height of $10 \mathrm{~m}$ from climatic average measured values (1961-1990) from 3615 stations covering the world and adjusted to the IMAGE-grid (New et al., 1997, 1999). ${ }^{10}$ Important assumptions in our estimate of the geographical potential are:

- the adjusted average wind speed should exceed $4 \mathrm{~m} \mathrm{~s}^{-1}$ at a height of $10 \mathrm{~m}^{11}$;

- geographical constraints: urban land $\left(u_{i}\right)$ and land above $2000 \mathrm{~m}\left(a_{i}\right)$ are excluded;

- constraints due to land use such as agriculture $\left(w_{i}\right)$ and bioreserves $\left(b_{i}\right)$ have been taken from IMAGE-data for the year 1995 (IMAGE-team, 2001).

For the technical potential, the most relevant assumptions are:

- a $1 \mathrm{MW}$ turbine with $69 \mathrm{~m}$ hub height is the reference and wind speed data are adjusted for this hub height of $69 \mathrm{~m}$ according to the standard height correction formula and estimates of the roughness length for each grid-cell;

- the full-load hours of operation can be approximated with a linear function of the annual average windspeed (based on Abed and El-Mallah, 1997);

- explicit assumptions have been made about the average turbine availability, wind farm array efficiency and spacing, and, relatedly, power density ${ }^{12}$; this has not

\footnotetext{
${ }^{10}$ The coverage of the stations is highest in Europe and lowest in Oceania. There are various sources of errors, which have partly attempted to correct for (New et al., 1999). Adjustment, (also for solar irradiance) was necessary because the co-ordinates of the CRU wind speed data do not completely match with the definition of grid cells in IMAGE 2.2, especially with regard to the definition of land versus sea.

${ }^{11}$ Other analyses have used stricter criteria, e.g. a wind regime above 6.0 or $5.1 \mathrm{~m} \mathrm{~s}^{-1}$ at $10 \mathrm{~m}$ (Grubb and Meyer, 1993; World Energy Council, 1994), partly on economic grounds. In our approach such sites would show up in the upper end of the LSCC. Also, the database we use (see footnote 2) gives one single number for the annual average wind speed at the specified resolution of $0.5^{\circ} \times 0.5^{\circ}$. Such values are rather low $(80 \%$ of the land area has an annual average wind speed lower than $4 \mathrm{~m} \mathrm{~s}^{-1}$ at $10 \mathrm{~m}$ in the CRU database) and neglect the potential large spatial and temporal fluctuations which could make wind turbines attractive.

${ }^{12}$ The assumption on power density $D$ implies that on any given area designated as 'suitable' $\left(f_{i}\right)$, one can either install many small or a few big installations. For instance, $D=1 \mathrm{MW} \mathrm{km}^{-2}$ can be as a single $1 \mathrm{MW}$
} 
differentiated across grid-cells i.e. one parameter choice for the whole world.

Of course, at this level of aggregation any assumption on the variables can be contested so we add a sensitivity analysis in the next paragraph. For instance, extreme wind speed distributions may yield results quite out of the range of our regression-based relationship. The third and last step is an estimation of the on-site generating costs. We use the standard engineering cost approach:

$C_{\text {Welec }, i}=\frac{a\left(1+O M_{w}\right) I_{w} D}{E_{i}} \quad \$ \mathrm{kWh}^{-1}$

with $C_{\text {Welec,i }}$ the production cost of electricity in grid cell $i$ $\left(\$ \mathrm{kWh}^{-1}\right) ; a$ the annuity factor $\left(\right.$ year $\left.^{-1}\right)$, and $O M_{w}$ the cost of operation and maintenance as a fraction of the investment cost. ${ }^{13}$ We use site-independent estimates for the various parameters (cf. appendices). The cost for grid connection and infrastructure are set at $1 \phi \mathrm{kWh}^{-1}$, based on (EWEA/Greenpeace, 2002).

\subsection{Electricity from solar-PV}

We confine ourselves to centralised grid-connected PV systems: semi- to large-scale systems $(10 \mathrm{kWp}$ to many $\mathrm{MWp}){ }^{14}$ installed on the ground. As primary resource data we use the average monthly irradiance $I_{i}\left(\mathrm{~W} \mathrm{~m}^{-2}\right)$ for a surface grid $\left(0.5^{\circ} \times 0.5^{\circ}\right)$ constructed from measurements at 4040 stations covering the world in the period 1961-1990 and adjusted to the IMAGE-grid (New et al., 1997). ${ }^{15}$ Values in between the stations are determined using an interpolation method as a function of longitude, latitude and elevation. Yearly average values range from a low $60 \mathrm{~W} \mathrm{~m}^{-2}$ at the highest latitudes to a high $250 \mathrm{~W} \mathrm{~m}^{-2}$ in some desert areas in Western and Northern Africa and Australia. Since the absorption of radiation in the atmosphere is included in the CRU data, the results differ from the numbers derived theoretically.

The conversion from solar irradiance data at grid-cell level into the technical potential i.e. extractable solar-PVbased electric power is similar to the one for wind energy (cf. Eqs. (1) and (2)). Some considerations in estimating the suitability/availability factor $f_{i}$ for centralized systems are: cropland area is restricted to small parts next to infrastructure or fallow area; extensive grassland is given a higher suitability/availability factor than agricultural areas; nature-protected and forest areas are excluded, as

\footnotetext{
(footnote continued)

turbine in the center of a grid-square or as 4 turbines of $250 \mathrm{~kW}$ at halfway between the square center and square corner.

${ }^{13}$ Annuitizing is done in the usual way: $a=r /[1-(1+r)-L]$ with $r$ the interest rate and $L$ the economic lifetime.

${ }^{14}$ The unit Watt-peak (Wp) refers to the produced power under standard test condition (STC), i.e., a module is illuminated with light characterized by an AM1.5 spectrum at a total intensity of $1000 \mathrm{~W} \mathrm{~m}^{-2}$ while held at a temperature of $25^{\circ} \mathrm{C}$.

${ }^{15}$ The data represent the irradiance at a horizontal plane and include both direct and diffuse irradiance. See also footnote 10 .
}

well as urban areas for which we assume decentralised systems to be preferred over centralised ones. We have also used estimates made in other analyses (Weingart, 1978; Sørensen, 2000). ${ }^{16}$ The final step: the calculation of the economic potential, is done similarly to the procedure for wind.

\section{Renewable energy potentials: uncertainties and scenarios}

\subsection{Dealing with uncertainties}

Any assessment of the potential supply of renewable energy at a regional/global scale implies significant uncertainties. Using a grid-cell level analysis, one has to balance the availability of data and the local variation on the one hand and their relevance for the WSB potentials on the other. An additional complication is that most parameters are time dependant in ways which are hard or not at all to forecast. Our approach has been to identify those parameters which are largely physical in nature and to analyse the uncertainties generated by extrapolating limited observations across large areas and over time. The remaining parameters often depend on rather complex, location and time-dependent developments in society. For these, we use the scenario approach, i.e. we estimate plausible 'best' values in the context of a narrative (storyline) about the future. Thus, we distinguish three uncertainty categories in the parameters:

(1) those that are totally or largely based on scientific measurement/observation; for these one can use conventional sensitivity analysis and their values can be expected to improve in quality over time;

(2) those that depend on complex interactions between social, economic and technical variables but for which different values can be used to make meaningful differentiation within a scenario storyline context and on the basis of existing literature; and

(3) those that also depend on complex interactions between social, economic and technical variables, but for which no direct argument could be made to connect their values to scenario storylines; for these parameters, one value has been chosen across all scenarios.

Table 1 indicates which factors have been considered in the analysis, and in which uncertainty class they are placed. The most obvious and relevant class 1 parameters are the average grid-cell values for wind speed and solar irradiation. These are assumed to be homogeneous within any grid-cell and constant over time. Important class 2 parameters are yields, conversion efficiencies and costs,

\footnotetext{
${ }^{16}$ In IMAGE 2.2 values for the urban area were derived from the $1 \mathrm{~km} \times 1 \mathrm{~km}$ DIScover database (Loveland and Belward, 1997). This database, in which urban area is defined as land covered by buildings and other man-made structures, has been converted to $0.5^{\circ} \times 0.5^{\circ}$ grid cells to construct a database giving the fraction of urban area in each IMAGE grid cell.
} 
Table 1

Different important uncertainties determining WSB potential

\begin{tabular}{|c|c|c|c|}
\hline Category & Wind & Solar & Biomass \\
\hline Population and GDP & & $\begin{array}{l}\text { SRES-scenarios (IMAGE-team, } \\
\text { 2001) }\end{array}$ & \\
\hline $\begin{array}{l}\text { Land-use land cover } \\
\text { (change) including food trade and } \\
\text { meat consumption }\end{array}$ & & $\begin{array}{l}\text { SRES-scenarios (IMAGE-team, } \\
\text { 2001) }\end{array}$ & \\
\hline Resource base & $\begin{array}{l}\text { Average wind speed } \\
\text { Roughness factor } \\
\text { Land suit/avail factors }\end{array}$ & $\begin{array}{l}\text { Solar irradiation } \\
\text { Land suit/avail factors }\end{array}$ & $\begin{array}{l}\text { Energy plantation yield } \\
\text { Land suit/avail factors }\end{array}$ \\
\hline Technology & $\begin{array}{l}\text { Average turbine size } \\
\text { Conversion efficiency }\end{array}$ & $\begin{array}{l}\text { Average solar- } P V \text { plant scale } \\
\text { Conversion efficiency }\end{array}$ & $\begin{array}{l}\text { Management factor } \\
\text { Conversion efficiency }\end{array}$ \\
\hline Economic & $\begin{array}{l}\text { Specific investment cost } \\
\text { Interest rate } \\
\text { Transport cost }\end{array}$ & $\begin{array}{l}\text { Specific investment cost } \\
\text { Interest rate } \\
\text { Transport cost }\end{array}$ & $\begin{array}{l}\text { Specific investment cost } \\
\text { Wage rate } \\
\text { Interest rate } \\
\text { Transport cost }\end{array}$ \\
\hline
\end{tabular}

The three uncertainty categories are indicated in plain: class 1; italic: class 2; and bold: class 3 .

learning coefficients and typical scenario variables such as population and economic growth paths and management factors. Usually, they vary with scale, manufacturer, location and time and one would like to have a representative average value at any given place and time. In practice, we have tried to strike a balance between feasibility on the one hand and available data and insights on the other. This has resulted in regional, but not local differentiation in conversion efficiencies $\left(\eta_{i}\right)$ and power densities $\left(D_{i}\right)$ and in some economic parameters (cf. Appendices). The most important class 3 parameters are the land-use suitability/availability factors. Indeed, one could imagine linkages between $f_{i}$ and a scenario storyline. For instance, a majority of people may in an environmentoriented scenario (B1 or B2, see below) wish to restrict biodiversity impacts of WSB which would low $f_{i}$-values make a consistent choice. However, if one assumes a global orientation (B1, see below), the seriousness of global environmental problems like climate change could justify the acceptance of more widespread introduction of WSBoptions c.q. high $f_{i}$-values. Given this ambiguity and in order to increase comparability across the scenarios, we have decided to use the same set of $f_{i}$ across the scenarios in this paper.

\subsection{The four scenarios and the land-use land cover changes}

The scenario analysis in this paper focuses on uncertainties in land-use land cover and in specific techno-economic WSB parameters. We used the four land-use scenarios that were developed using the IMAGE-model (IMAGE-team, 2001; Strengers et al., 2004), based on the four qualitative storylines developed in the context of the IPCC (Nakicenovic et al., 2000). These four storylines can be represented along two axes, one indicating people's orientation towards economic/material issues and one reflecting the tendency towards globalization/regionalization. From this, four scenario 'families' have been constructed (Fig. 1: A1, A2,
B1, B2). ${ }^{17}$ Land-use land cover differs in the scenarios due to different growth rates for regional population and economic activity (i.e. gross domestic product or GDP) as well as meat consumption, agrotechnological changes and food trade.

The A1 storyline, which is used as reference, describes a trend towards a hightech and increasingly interconnected world, driven by an orientation on markets, deregulation and the removal of trade barriers. It would combine high economic growth, and, partly as a consequence, low population growth. The A2 storyline is an alternative development path, dominated by economic and cultural protectionism and driven by factors such as resistance against 'modernisation' and concern about regional identity. Such a world would experience low economic growth and high population growth. In the B1 storyline of increasing global interdependence and increasing concern and policies for environmental integrity and social justice, economic growth in currently low-income regions would be high and population growth relatively low. Finally, the B2 storyline describes a development path with a strong orientation on local/regional well-being in a broad sense, with medium assumptions for economic and population growth.

The scenario families are best interpreted as archetypical futures along which the world system might evolve. Realworld developments could follow any combination of these, in the sense that over time and across the many facets of the world system the emphasis may shift from one scenario to another. More or less unexpected and/or extreme events such as terrorist attacks, oil supply crises, or a severe and sudden disease outburst or climate disruption could cause a more or less enduring shift from one scenario family to another one- and hence change the prospects for WSB-options.

\footnotetext{
${ }^{17}$ See for more details on these scenarios: www.mnp.nl or www.ciesin.org. We have used the parameter settings of the A1B storyline.
} 


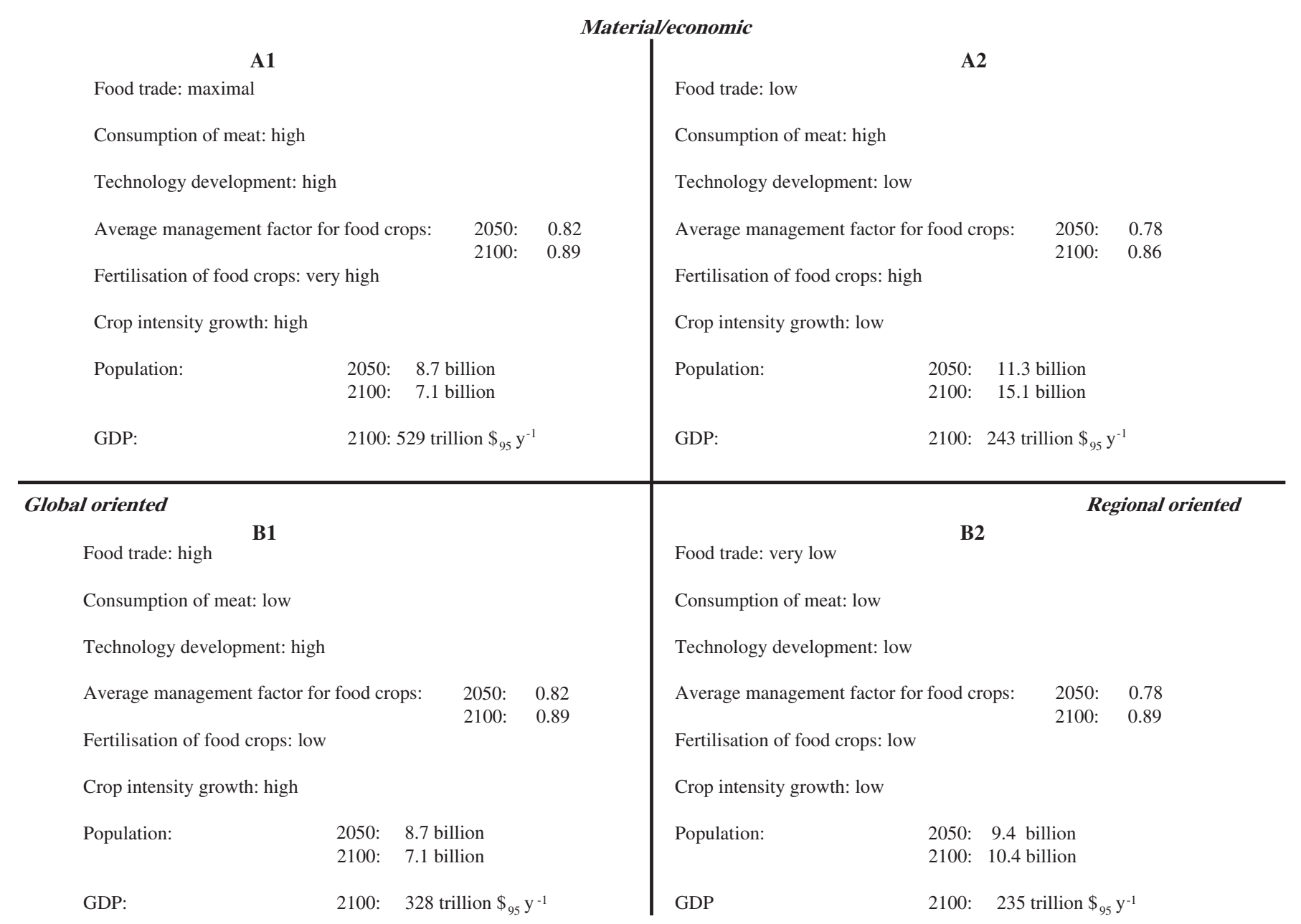

\section{Environment/Social}

Fig. 1. Schematic overview of the scenarios used and of the main assumptions to simulate the land-use dynamics in the IMAGE 2.2 SRES implementation (IMAGE-team, 2001).

Fig. 1 summarizes the assumptions for the four narratives used to in this analysis to simulate the land-use dynamics in the IMAGE 2.2 model. The four scenarios lead for the period considered (2000-2050) to divergent land-use land cover projections (Fig. 2). In all scenarios agricultural land is taken out of production, either because of surplus agricultural land or shifts in production patterns. The area of abandoned agricultural land is highest in the B1 and A1 scenarios, mainly due to surplus agricultural land as a consequence of a stabilizing world population and fast and widespread yield improvements. On the other extreme, high population growth and slow technological improvements in the A2 scenario result in a higher demand for land-for-food and, subsequently, in less abandoned agricultural land and less forested land due to the production of food and fodder.

To assess the WSB-potential we assigned values to the suitability/availability factors $f_{i}$, the same for all four scenarios (class 3; cf. Table 2). Certain land-use/cover classes are completely excluded - such as urban areas, nature reserves and inaccessible ice. Also, forested areas are (almost) completely excluded. The huge grassland ecosys- tem areas, including the scrublands and savannahs, are considered to be available for all three WSB-options for a quarter or less. The hot desert and tundra areas are considered to be less accessible under normal circumstances. For all these land areas, we reckon that after initial penetration in the more favourable locations - based on criteria such as demand proximity, landscape features, etc.-counterforces will make further penetration more difficult. Such forces may have to do with nature conservationists resistance, transport barriers, interference with other land functions such as nomadism and tourism/ recreation, etc. ${ }^{18}$ Here, the most interesting category are the abandoned agricultural lands. We consider these to be available up to $80-90 \% .{ }^{19}$ Besides these considerations, the values are based on estimates and arguments used by other authors (British Wind Energy Association (BWEA), 2000;

\footnotetext{
${ }^{18}$ Recently, a vigorous debate has grown about the trade-off between conservation of biodiversity on the one hand and large-scale introduction of biofuel plantations on the other, see Brink et al. (2006).

${ }^{19}$ The inhabited parts are excluded: the areas refer to the not inhabited parts of the areas which are at any given time no longer used for agriculture.
} 

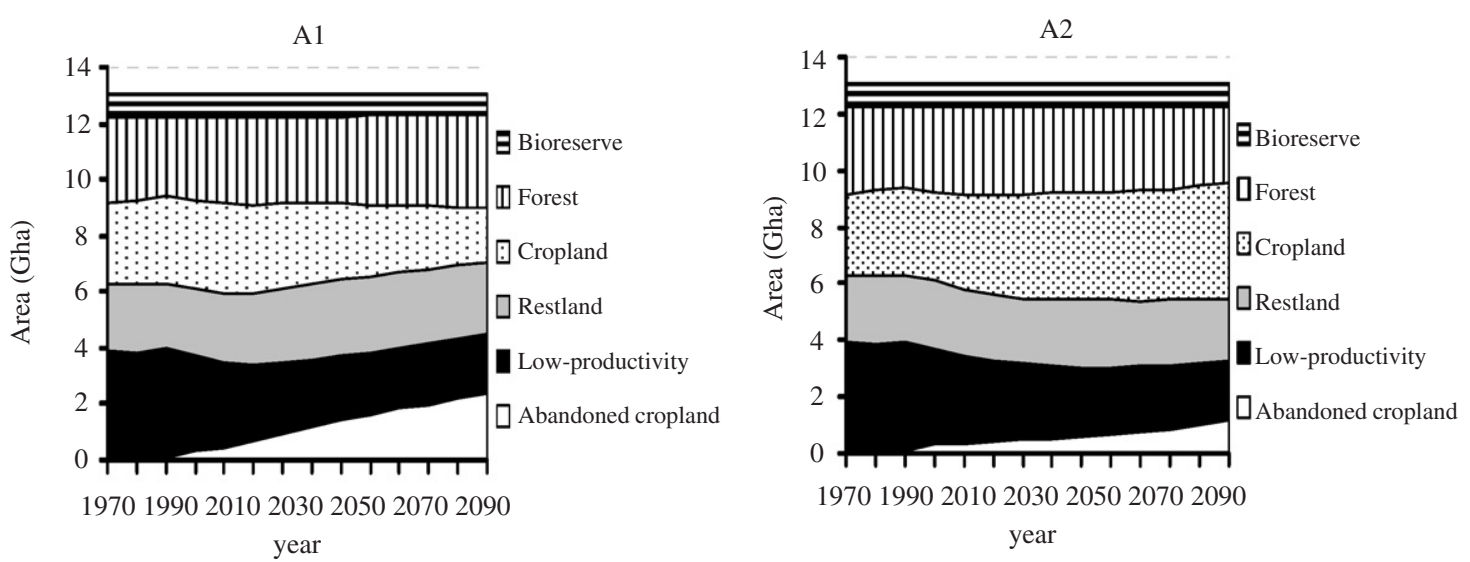

B1

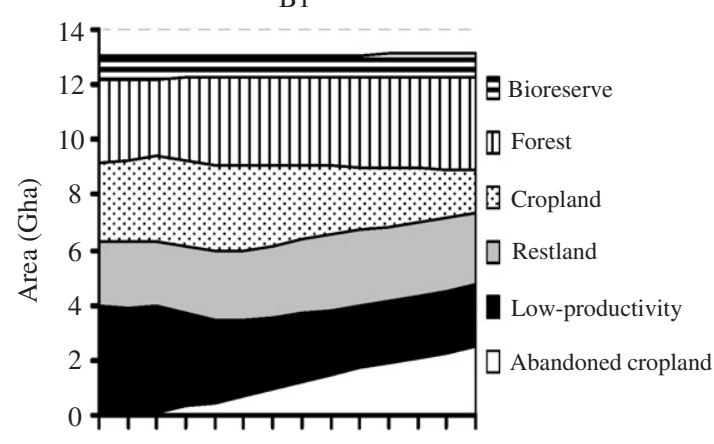

1970199020102030205020702090

year

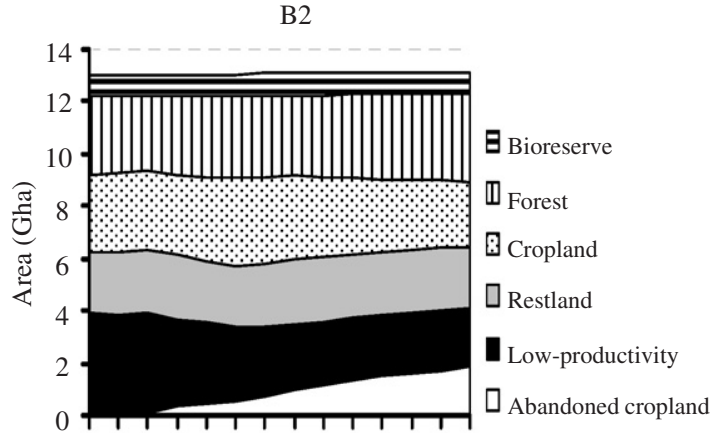

1970199020102030205020702090

year

Fig. 2. Land-use land cover changes in the IMAGE 2.2 IPCC SRES scenarios, used as the basis for the estimation of the primary biomass production potential.

Table 2

Assumed suitability fraction in \% by land use category: default values and (between brackets) boundary values

\begin{tabular}{lll}
\hline Land-use category included & Wind & Solar-PV \\
\hline Agricultural land & $60(30 / 90)$ & 0 \\
Abandoned agricultural land & $80(50 / 90)$ & $80(50 / 90)$ \\
Extensive grassland, grassland and steppe, scrubland, savannah & $20(10 / 25)$ & $10(5 / 15)$ \\
Hot desert, wooded tundra & $10(5 / 20)$ & $5(2.5 / 10)$ \\
Temperate deciduous/mixed forest, warm mixed forest, regrowth forest (timber) & $0(0 / 5)$ & 0 \\
Considered inaccessible and/or not permissible: & 0 & 0 \\
Ice, Boreal forest, cool conferous forest, Tropical woodland/forest & 0 & 0 \\
Urban area, nature reserve/development & 0 & 0 \\
\hline
\end{tabular}

Cabooter et al., 1999; Energy Information Agency (EIA), 1999; Elliot and Schwartz, 1993; German Advisory Council on Global Change (WBGU), 1999; World Commission on Protected Areas (WCPA), 2000). The divergence in scenario drivers lead to different land-use land cover patterns and thus to different calculated WSB-potentials.

\subsection{Future technological development}

Our assessment of the economic potential in the form of long-run supply cost curves or LSCC requires assumptions on future technological changes, notably in specific investment costs and conversion efficiencies and yields.
For the WSB energy sources, energy production cost have significantly declined in the past decades. Conceptually, one often deals with future cost developments by using a learning curve which postulates that the cost/performance parameter of the $i$ th unit, $C_{i}$, is a downward sloping function of cumulated output, $C=a Y^{-b}$, with $b$ the learning coefficient and $C$ usually the specific investment costs - in the case of WSB $€ \mathrm{kWe}^{-1}$ installed or $€ \mathrm{GJ}^{-1}$ year $^{-1}$ capacity. Such a relationship reflects aggregate trends in upscaling and mass production, incremental innovations and technological breakthroughs (IEA (International Energy Agency), 2000; Junginger et al., 2005). An overview of some current and future cost estimates 
Table 3

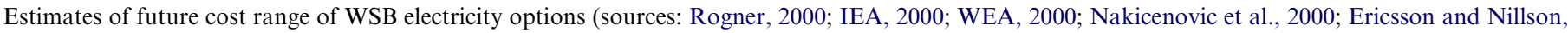
2004; ATLAS, 2005; Kobos et al., 2005; Nemet, 2005)

\begin{tabular}{|c|c|c|c|c|}
\hline & Current $(\$ / \mathrm{kWh})$ & Short term $(2010 / 2020)(\$ / k W h)$ & Medium term $(2030)(\$ / \mathrm{kWh})$ & Long term $(2050)(\$ / \mathrm{kWh})$ \\
\hline Wind & $0.05-0.13$ & $0.03-0.08$ & $0.03-0.05$ & $0.03-0.10$ \\
\hline Solar-PV & $0.25-1.25$ & $0.25-0.40$ & $0.15-0.30$ & $0.06-0.25$ \\
\hline Biomass & $0.05-0.10$ & $0.03-0.08$ & $0.03-0.04$ & $0.03-0.10$ \\
\hline
\end{tabular}

published in literature is given in Table 3. Our assumptions for this analysis have been based on these estimates and on estimates of the progress ratios from literature sources. Following the scenario storylines we assume technology progress in the A1 and B1 scenario to be rapid - and thus consistent with the lower cost estimates mentioned in Table 3. In contrast, we assume technological progress in the A2 and $\mathrm{B} 2$ scenario to be slow and medium, respectively, and thus consistent with the upper and medium values, respectively, of the range in Table 3. The cost trajectories over time have been translated into specific, exogenous parameter assumptions. Appendix B presents all assumptions for each of the scenarios.

For energy from biomass, technological progress has been introduced via the management factor MF and via improvements in both production and conversion equipment. A change in the MF implies a change in the yield of energy crops $Y_{i}$ through better management, biotechnology and fertilizer use (cf. Eq. (4)). We assume an exogenous increase of MF from the 2000-value of 0.7 to values between 1.3 and 1.5 by 2050 depending on the scenario. For wind energy the cost decline stems largely from increasing turbine size, from $200 \mathrm{~kW}$ in 1990 to about $1.5 \mathrm{MW}$ in 2002 (EWEA/Greenpeace, 2002). For wind energy progress ratios have been found of $0.85-0.96$ or $15-4 \%$ reduction per doubling (EWEA/Greenpeace, 2002). For solar-PV the declining specific investment costs came from innovations in conversion efficiency and modulebased production techniques. The module selling price has been falling continuously, from about $55 \$_{2002} \mathrm{Wp}^{-1}$ (Harmon, 2000) in 1979 to world average PV module prices of 3-6 $\$ \mathrm{Wp}^{-1}$ in 2002 (solarbuzz, 2002). Past experience suggests a $20 \%$ cost decline with every doubling of cumulated generating output i.e. a progress ratio of about 0.8 . We assume a further drop, in one scenario to as low as $0.5-1 \$ \mathrm{Wp}^{-1}$ after 2015 (Turkenburg, 2000). For biomassbased electricity generation we assume similar learning-bydoing progress as for windpower.

\section{Worldwide renewable energy supply vs. cost potentials}

In the previous section we have sketched the generic methodology, the parameter choices and their uncertainties - we are now ready to present the results. We first discuss the potential for various cut-off cost levels for each of the WSB-options. Next, we present the summed potentials taking into account interactions. Finally, these results are examined in the context of existing developments and policy regimes and longer term penetration dynamics.

\subsection{The world-wide potential for liquid biofuels for transport}

Fig. 3 shows the global potential production of liquid biofuel at different cost categories by scenario. In the year 2000 , this potential amounts, after conversion to final energy carrier, to $30-40 \mathrm{EJ}_{\text {year }}{ }^{-1}$ according to the methodology applied. Fig. 4 shows for the scenario with highest (A1) and lowest (A2) potential the regional breakdown. Most of this potential comes from abandoned agricultural and grassland areas in Europe, USA and the Former Soviet Union (FSU). In addition, savannah and grassland areas in South America, Africa, South-East Asia and Australia add to this, in fact giving the lowest production costs. It stems largely from woody biofuels and maize in the temperate zones and from sugar crops in the tropical zones.

By 2050, in all four scenarios the total potential has expanded - to about $75 \mathrm{EJ}_{\text {year }}{ }^{-1}$ in A2, $175 \mathrm{EJ}_{\text {year }}{ }^{-1}$ in B2 and $250-300 \mathrm{EJ}$ year $^{-1}$ in A1-B1. The expansion is mainly driven by an increasing area of abandoned agricultural land, and, to a far lesser degree, increasing conversion efficiencies. In the two high-tech high-growth scenarios (A1 and B1), some $80 \mathrm{EJ} \mathrm{year}^{-1}$ can be produced at costs between 10 and $121995 \$ \mathrm{GJ}^{-1}$ and about 200 EJ year ${ }^{-1}$ between 12 and $151995 \$ \mathrm{GJ}^{-1}$ or twice to thrice the costs at which transport fuels are currently produced from oil. This high potential in A1 and B1 is mainly from modest population cq. food demand growth and increasing agricultural yield and trade. In contrast, slow yield improvement and high population give a low potential in A2. In addition to the changes in total potential, Figs. 3 and 4 also show that costs are assumed to come down substantially in most scenarios. While costs range from 10 to over $20 \mathrm{US} \mathrm{GJ}^{-1}$ in 2000 , in both the $\mathrm{A} 1$ and the B1 scenario more than $25 \%$ of the potential is assumed to be available by 2050 at costs below $12 \mathrm{US} \mathrm{GJ}^{-1}$. As a comparison of the potential production to global transport fuel demand in each of the scenarios shows (Fig. 3), biofuel could by 2050 technically speaking supply $100 \%$ of global transport fuel demand in 3 out of the 4 scenarios if all the land considered suitable/available for biomass plantations were to be used for the production of transport fuel. 


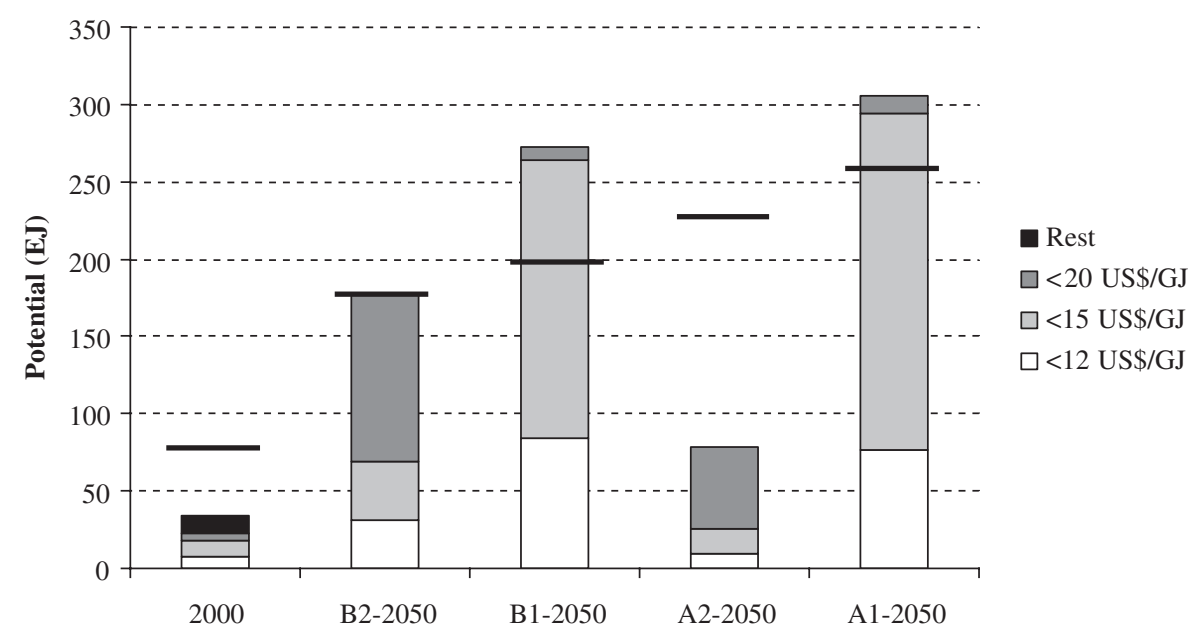

Fig. 3. Potential global biofuel production for four production cost categories (IMAGE-team, 2001). The horizontal line indicates historical cq. estimated future. transport energy demand.
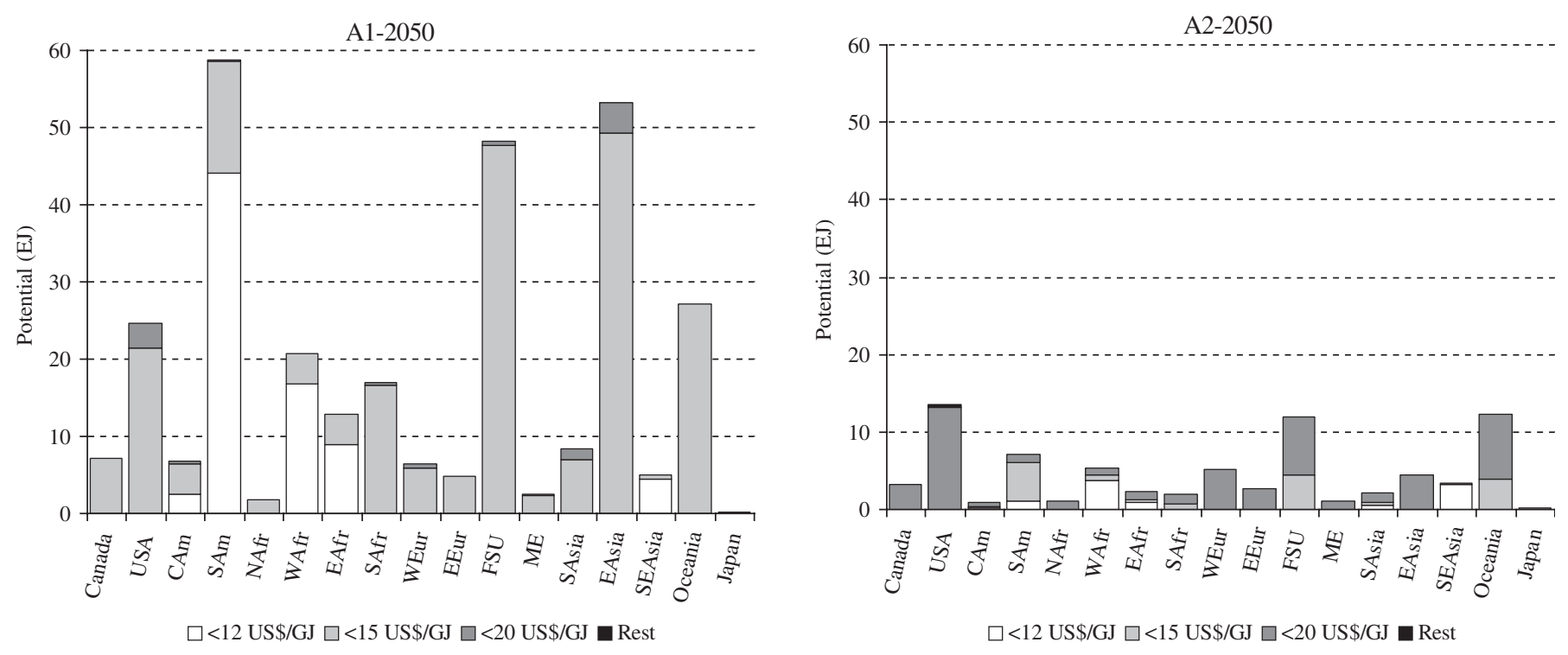

Fig. 4. Regional biofuel production potential for the A1 and A2 scenario in 2050. The same colour code is used for the production cost categories as in Fig. 3 (white: <12 \$/GJ; grey: <15 \$/GJ; dark grey: <20 \$/GJ; black: other).

The regional breakdown (Fig. 4) suggests that in particular South America, the FSU, East Asia, Oceania and the USA could by 2050 contribute to the biofuel potential expansion under the A1 scenario. However, low cost biofuel production options are restricted to the tropical regions (South America, Africa, and South East Asia), making these regions attractive for biofuel export. The difference between the A2 and the A1 scenario is largely the reduced potential in South and Central America and West and East Africa: whereas the potential in the moderate temperature regions is halved, it falls with over $80 \%$ in the tropical regions. The lower potential estimate in the A2 scenario is a direct consequence of more people hence higher food demand and lower yield (improvement) hence more land demand - one aspect of the food vs. energy nexus.

\subsection{The world-wide potential for electricity from WSB (individual options)}

Electricity can be generated from all three WSB energy sources - but they do compete for land as all three are land-intensive, though to varying degrees. This can already be shown with a 'back-of-the-envelope' calculation. Let us put the average solar irradiation at $150 \mathrm{~W} \mathrm{~m}^{-2}$, the average wind speed at $6 \mathrm{~m} \mathrm{~s}^{-1}$ at hub height and the average biomass production at 10 ton $^{-1} \mathrm{year}^{-1}$. Using these values and a suitability/availability factor of 1 , we find a theoretical electricity production density of about 18 (solar-PV), 7 (wind) and $2 \mathrm{GWh}_{\text {year }}{ }^{-1} \mathrm{~km}^{-2}$ (biomass). ${ }^{20}$

\footnotetext{
${ }^{20}$ Other assumptions are: conversion efficiencies of $14 \%$ (for solar-PV) and of $40 \%$ (for biomass) and a lower heating value (LHV) of
} 
Table 4

Estimated technical potential of the three WSB options in PWh year ${ }^{-1}$ for the 17 regions. World electricity use is about $13.3 \mathrm{PWh}(2001)$

\begin{tabular}{|c|c|c|c|c|c|c|}
\hline & \multicolumn{3}{|l|}{2000} & \multicolumn{3}{|l|}{2050} \\
\hline & Wind & Solar-PV & Biomass & Wind & Solar-PV & Biomass \\
\hline Canada & 3 & 18 & 0 & 4 & 82 & 2 \\
\hline USA & 16 & 73 & 1 & 22 & 255 & 5 \\
\hline Central America & 2 & 12 & 0 & 2 & 84 & 1 \\
\hline South America & 3 & 64 & 1 & 5 & 505 & 8 \\
\hline Northern Africa & 1 & 62 & 0 & 1 & 148 & 0 \\
\hline Western Africa & 0 & 96 & 1 & 0 & 333 & 3 \\
\hline Eastern Africa & 1 & 52 & 0 & 1 & 240 & 3 \\
\hline Southern Africa & 0 & 60 & 0 & 0 & 336 & 3 \\
\hline OECD Europe & 3 & 19 & 0 & 5 & 46 & 2 \\
\hline Eastern Europe & 0 & 5 & 0 & 1 & 42 & 1 \\
\hline Former Soviet-Union (FSU) & 8 & 146 & 1 & 11 & 556 & 11 \\
\hline Middle East & 1 & 85 & 0 & 1 & 174 & 1 \\
\hline South Asia (incl. India) & 1 & 54 & 0 & 1 & 192 & 2 \\
\hline East Asia (incl. China) & 1 & 58 & 0 & 2 & 640 & 11 \\
\hline South East Asia & 0 & 17 & 0 & 0 & 25 & 1 \\
\hline Oceania & 4 & 118 & 1 & 6 & 443 & 5 \\
\hline Japan & 0 & 1 & 0 & 0 & 2 & 0 \\
\hline Total & 43 & 939 & 7 & 61 & 4105 & 59 \\
\hline
\end{tabular}

The worldwide technical potential is the product of electricity production density and the suitable/available land area. Calculating this for all cells and summing up over regional areas yields the regional technical potentials for 2000 and 2050. It is shown in Table 4 for the landcover according to the A1-scenario and the assumptions presented in Table 2. The technical potential for the world as a whole is largest for solar-PV; the technical potential for wind is only some $2 \%$ of it. This is partly compensated by the higher land suitability/availability for wind (Table 2). Biomass-based electricity is limited in 2000 by the agricultural land abandoned-but becomes comparable to wind in 2050.

Using the cost formulas discussed in Section 2 and arranging the grid-cells according to generation costs for the regions, one gets the economic potential for different cut-off levels of electricity production cost. The maps in Fig. 5 show for the three options the locations at which electricity can be produced at a given cost, now and as estimated for 2050. In most of the scenarios, the situation changes considerably between 2000 and 2050 (Figs. 5-7). The strongest increase in potential for wind and biomass occurs in the A1 scenario and is driven by great improvements in yield and a stabilizing population and hence the lowest need for agricultural land. By 2050 the potential for electricity from wind is about 2 times and from biomass 6 times the estimated potential in 2000, largely confined to a few proliferous regions. In the B1 and B2 scenarios, the potential also grows but slower. Wind power costs come down on average by about $2-3 \phi \mathrm{kWh}^{-1}$ and is in some places generated at cost below $4 \notin \mathrm{kWh}^{-1}$ in

(footnote continued)

$15 \mathrm{GJ}$ ton $^{-1}$. The electricity production density in $\mathrm{GWh}_{\mathrm{year}} \mathrm{r}^{-2} \mathrm{~km}^{-2}$ can be seen as the inverse of the land productivity in $\mathrm{km}^{2} \mathrm{GWh}^{-1}$ year ${ }^{-1}$. the A1 and B1 scenarios. Similarly, electricity from biomass can be in some places be generated at less than $6 \notin \mathrm{kWh}^{-1}$. The prospects for biofuel will increase in temperate regions and grassland ecosystems. Our estimate of the WSB potential for the year 2000 at less than $8 \notin \mathrm{kWh}^{-1}$-which is about twice the costs of fossil-fuel based power-is about $7 \mathrm{PWh}_{\text {year }}{ }^{-1}$ for wind and for biomass. Below $10 \phi \mathrm{kWh}^{-1}$, these numbers are 20 and $7 \mathrm{PWh} \mathrm{year}^{-1}$, respectively. The higher cut-off cost level hardly affects the biomass potential - which is restricted by available land-whereas it improves the prospect for electricity from wind. This difference in supply elasticity is reflected in the supply cost curves (Fig. 6). For solar-PV, the potential for the year 2050 depends crucially on cost reducing innovations: for our cut-off cost level of $10 \propto \mathrm{kWh}$, a non-zero potential only emerges in the A1/ $\mathrm{B} 1$ future, but at higher costs the solar-PV is huge in all scenarios (Fig. 6).

\subsection{The world-wide potential for electricity from WSB (combined)}

Because all three WSB options require land for their operation, one cannot simply add the potentials. In qualitative terms one can imagine several forms of interaction due to competition for land, some of them negative and some positive. Operation of more than one WSB-option may cause additional costs due to physical exclusion and interference, but also lower costs due to economies of scale in construction, operation and infrastructure. In order to identify potentially very attractive areas for renewable energy production and to determine the overlap in the potential of the individual sources, we will now focus on those areas (grid-cells) where one or 

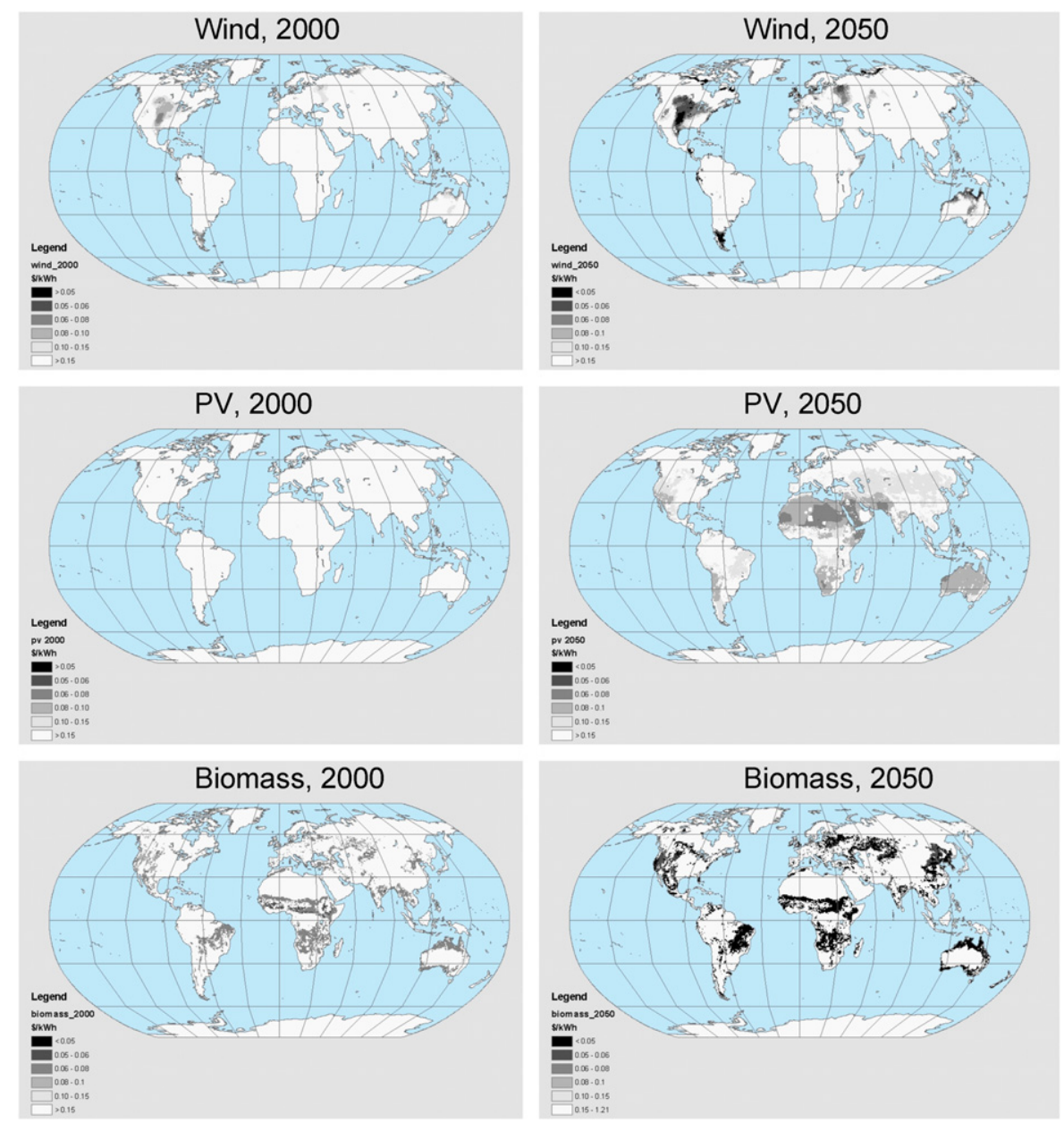

Fig. 5. Estimated costs of producing electricity in the A1 scenario for wind, biomass and solar-PV in 2000 and in 2050.
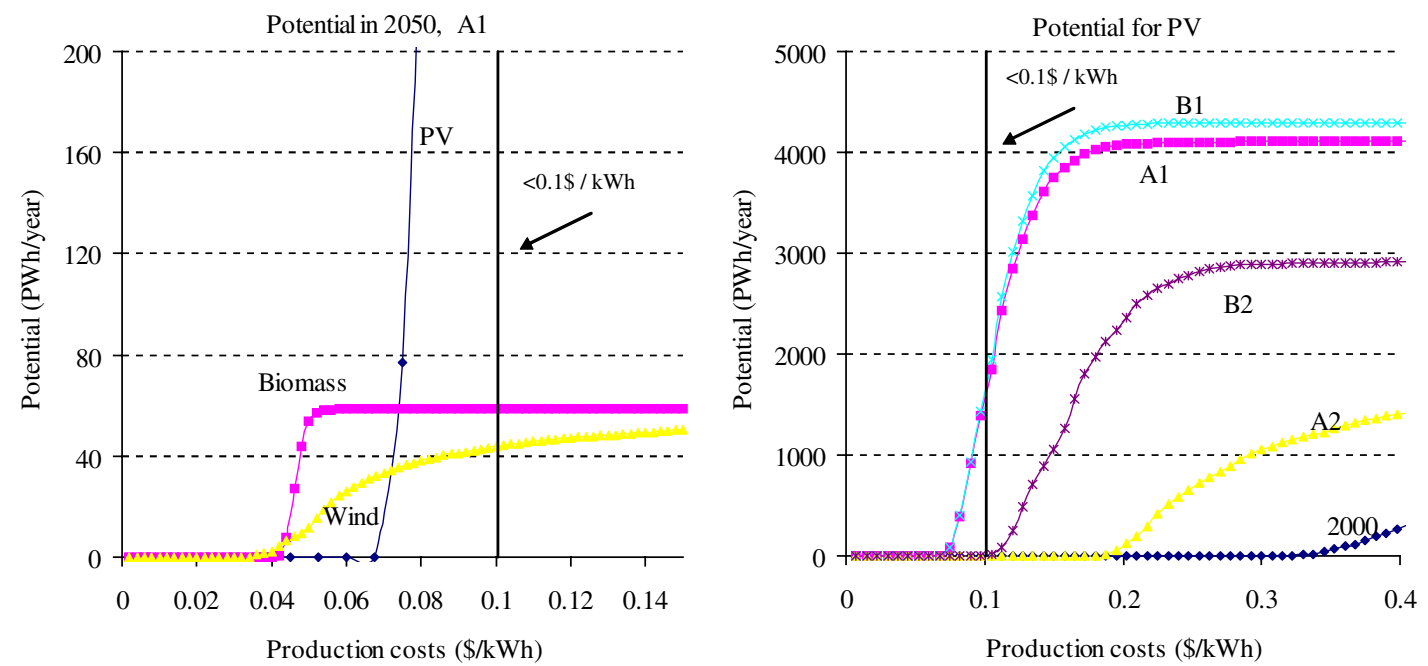

Fig. 6. Cost supply curve for the WSB-options in the A1 scenario in 2050 (left) and in all four scenarios for PV (right). The figure also shows the ' $0.1 \$$ / kWh' line used in this paper as an arbitrary cut-off cost in determining the economic potential (cf. Eq. (3)).

more of the WSB options can produce electricity at less than $10 \propto \mathrm{kWh}^{-1}$ in 2000 and 2050 (Fig. 8). We restrict the discussion to the scenarios with the highest and lowest potential, i.e. A1 and A2.
Fig. 8 (upper) shows that in the A1 scenario some form of WSB potential is available below $10 \phi \mathrm{kWh}^{-1}$ in almost all areas of the world. Electricity from solar-PV is available in vast tropical areas; electricity from wind is concentrated 

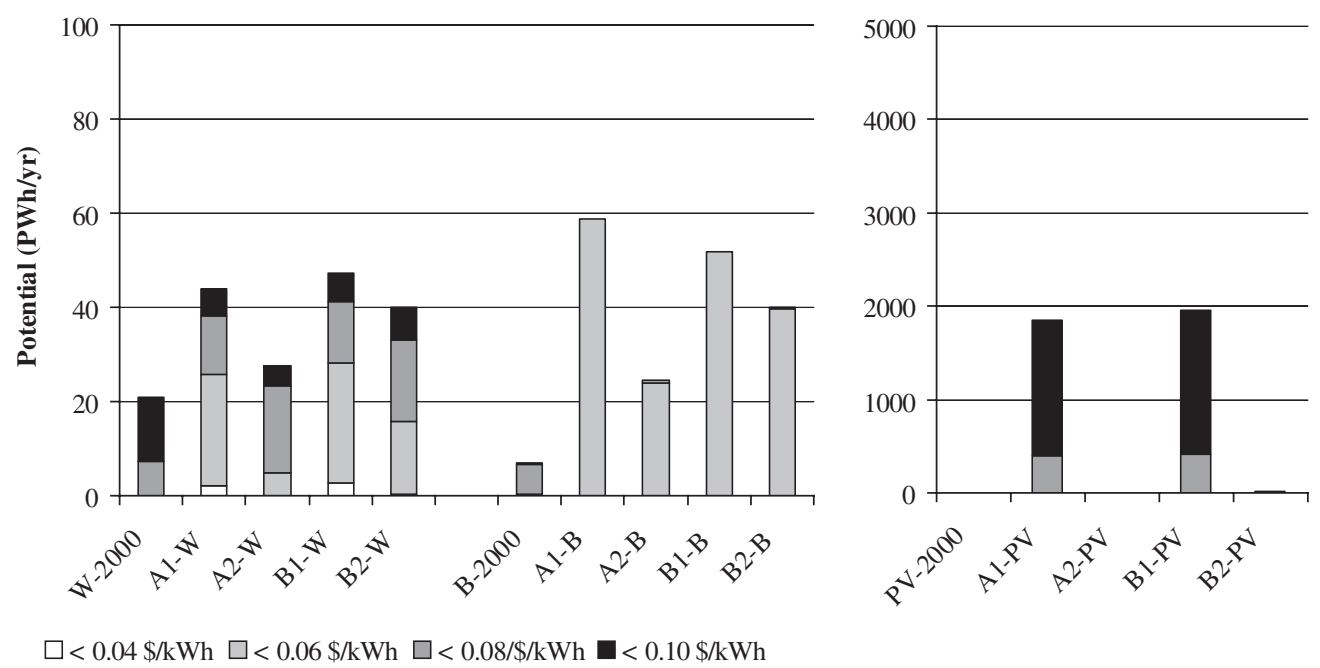

Fig. 7. The global technical potential for electricity from wind and biomass (left) and solar-PV (right) in the year 2000 and in the four scenarios for the year 2050 for four production cost categories.
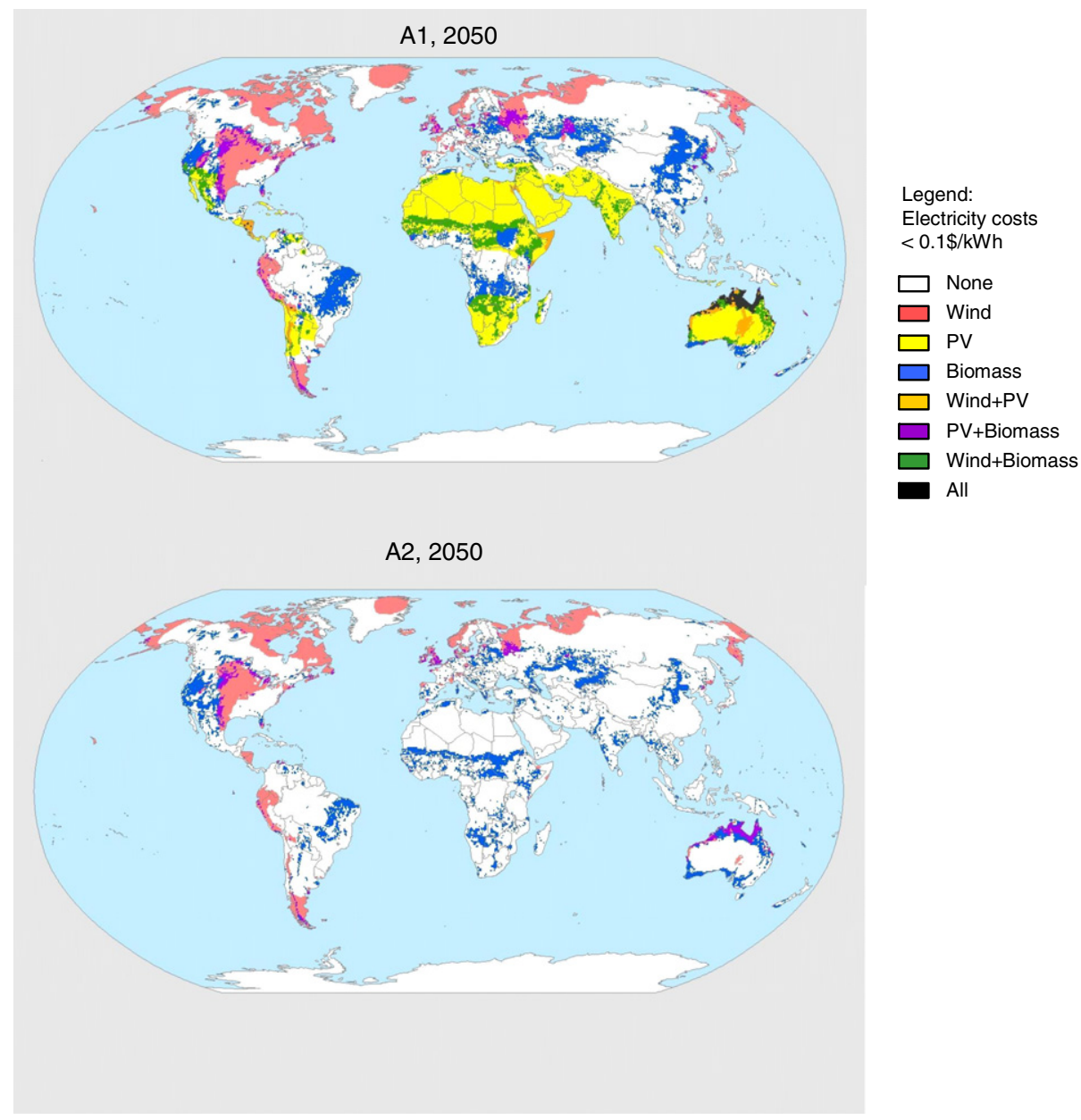

Fig. 8. Areas where in the A1 scenario (upper) and A2 scenario (lower) one or more of the WSB options is estimated to be able to produce electricity in 2050 at costs below $10 \notin \mathrm{kWh}^{-1}$.

in the temperate zones-but also some smaller areas in the tropical zones. Biomass can be produced on vast tracts of abandoned agricultural land in the USA, Europe and the FSU and on grasslands and savannah elsewhere. In large areas more than one form of WSB potential is available below this cost level. In many areas of India, China and Central America and Africa south of the Sahara at least one, and often two, forms of WSB is available below 

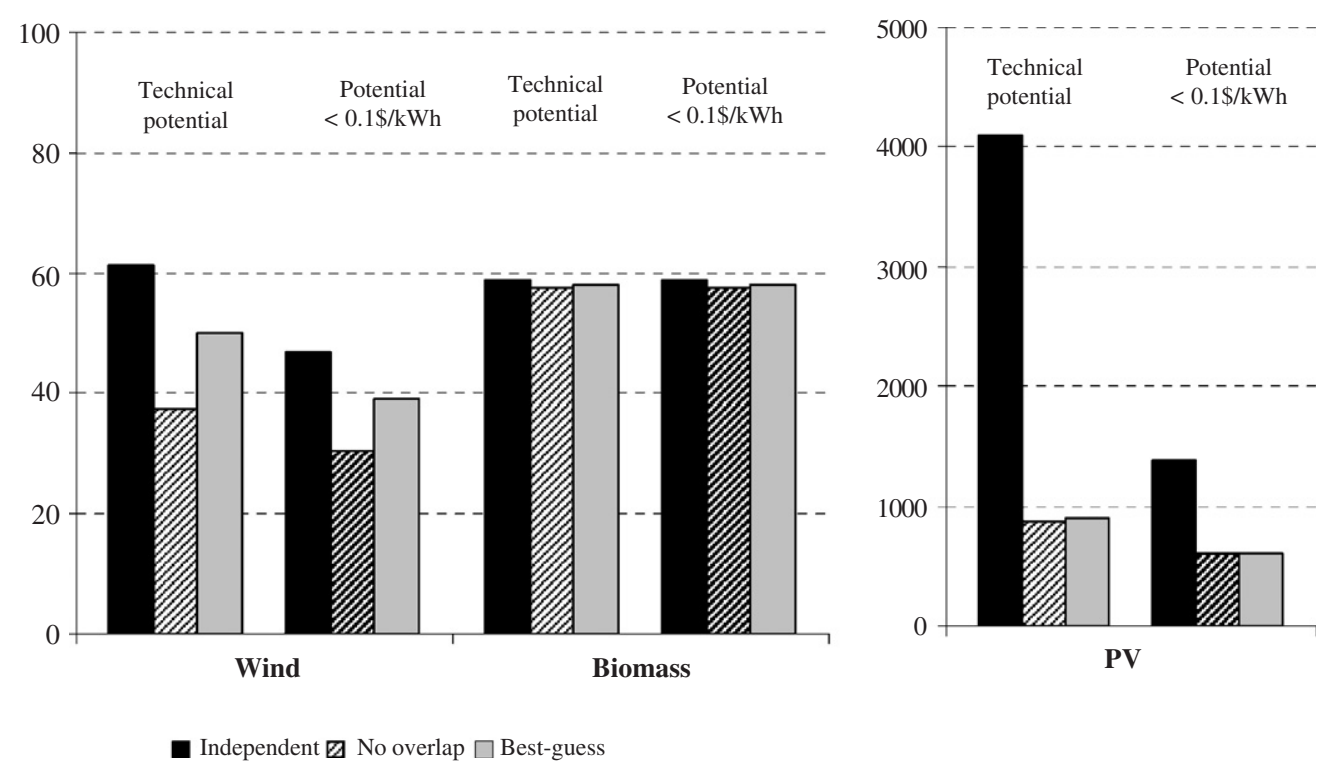

Fig. 9. The global technical and economic $\left(<10 \notin \mathrm{kWh}^{-1}\right)$ potential for wind, biomass and solar-PV in 2050 based on (a) independent assessment (cf. Section 4.2), (b) selecting only the cheapest option (cf. Section 4.3 method 2) and (c) allowing some overlap between wind potential and the two other options (cf. Section 4.3 method 1). Note that the solar-PV potential is indicated on a separate $y$-axis.

$10 \notin \mathrm{kWh}^{-1}$. This potential is the more interesting because it is available in areas where there is already now or in the near future a large demand for electricity - and nearby demand centres may diminish investment and operational system costs of WSB. It is also seen that in large and sometimes densely populated regions renewable energy sources are hardly or not at all available, given our assumptions. In the A2 scenario (Fig. 8 (lower)), the situation is much less favourable. There are still large areas in Africa, Australia and India where two or even three of the WSB-options can contribute, but outside these regions the potential to produce electricity below $10 \phi \mathrm{kWh}^{-1}$ is quite local and limited. Comparison of the two maps shows that in particular the slower decline in solar-PV costs and the higher demand for land-for-food are causing the difference.

In trying to combine the different potentials we need to establish which options compete for the same land. For instance, biomass plantations make it impossible to install solar-PV panels and in some places wind turbines may combine badly with solar-PV. On the other hand, a combination of wind turbines and local electricity-frombiomass or solar-PV may yield economies-of-scale in transport and storage systems, particularly in urban areas where infrastructure costs may be shared. We have used two methods for summing up the technical potentials across grid-cells and regions:

- In method 1, we use our best-guess: it is assumed that wind turbines can be combined with biomass plantations or solar-PV modules but only on half of the suitable/available area; and that the production of biofuel- and solar-PV-based electricity cannot be com- bined and therefore we consider only the lowest cost option in the grid-cell considered.

- In method 2 we are conservative: we assume that no dual land use is possible and in each cell only the lowest-cost option can be implemented.

The results are shown in Fig. 9. It turns out that competition for land with total exclusion of more than one option can for wind bring down the technical and economic potential with over one third. For solar-PV the decline is even larger, in the range of $75 \%$ (technical) and $55 \%$ (economic) because under our competition rules solar-PV is almost anywhere excluded except in the desert areas. For biomass the interaction with the other two options is minor. There are, however, significant differences in the competition effects across the regions. They are in absolute $\left(<3 \mathrm{PWh}_{\text {year }}{ }^{-1}\right)$ terms small or negligible in Central America, OECD and Eastern Europe, South East Asia and Japan. On the other hand, they are large in absolute $\left(>25 \mathrm{PWh}_{\text {year }}{ }^{-1}\right)$ or relative $(>2)$ terms in South America, all Africa, the FSU, South and East Asia and Oceania. This shows the importance of having a closer look at the nature of such competition and the associated (dis)advantages.

\subsection{Regional WSB-potentials and electricity demand}

The WSB-potential to generate electricity at costs below $10 \notin \mathrm{kWh}^{-1}$ is shown in Fig. 10 for the 17 regions and three options for the A1 scenario in the year 2050. The aggregate outcome is also shown for the other three scenario's. The outlook is dominated by solar-PV, particularly in the desert-rich regions of Africa, the Middle East and 


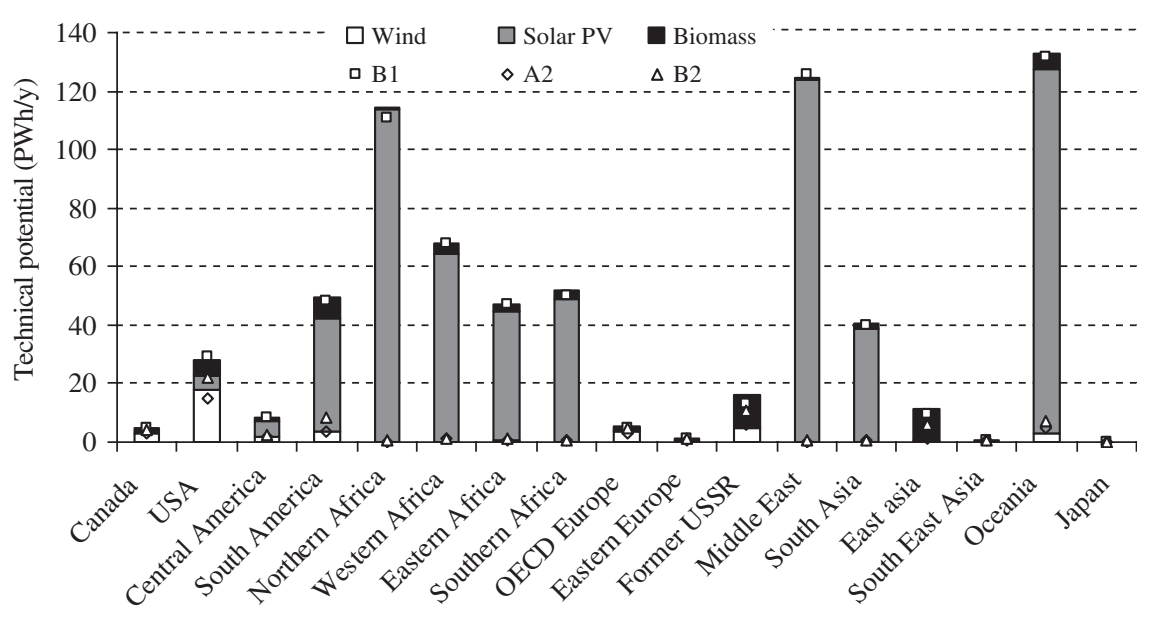

Fig. 10. The regional potential in 2050 (i.e. the technical potential at electricity production costs below $10 \notin \mathrm{kWh}^{-1}$ ) for wind, solar-PV and biomass in the A1 scenario; using the best-guess method. The corresponding values in the three other scenarios are also shown.

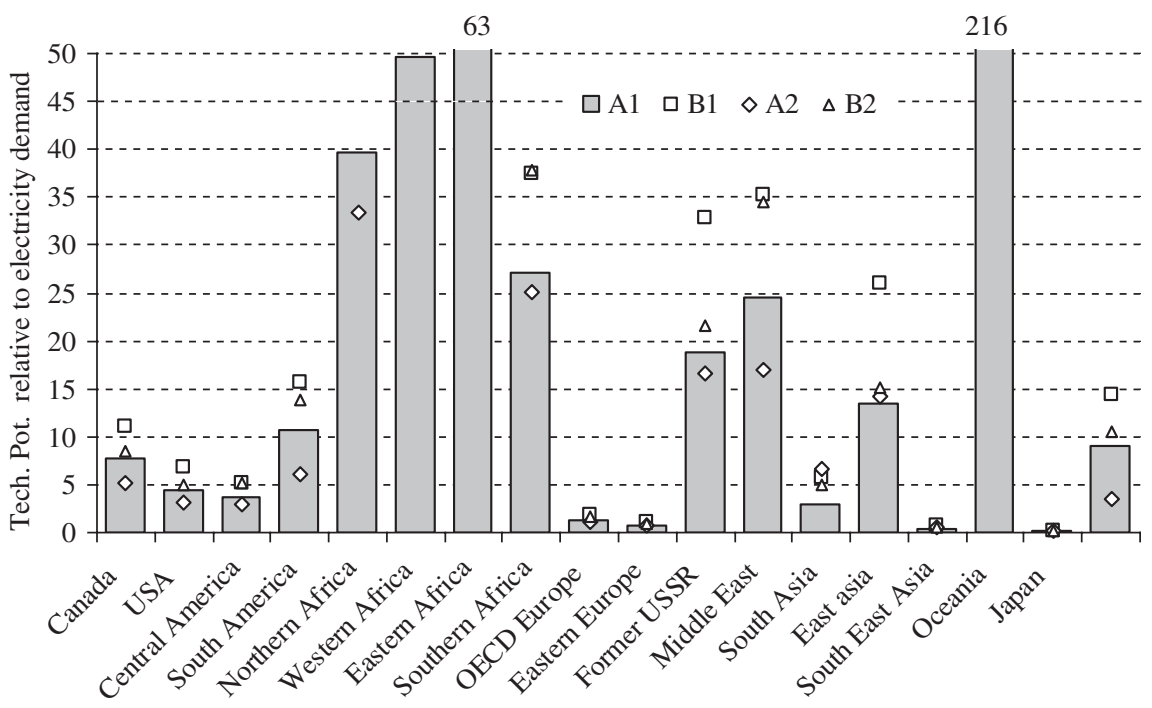

Fig. 11. Ratio between the potential supply of WSB below $0.1 \$ / \mathrm{kWh}$ in 2050 and the electricity demand according to the A1 scenario (bars) and the other 3 scenarios (marks).

Australia. Wind and biomass have globally a similar economic potential but in different regions: whereas wind could become a major energy source in the temperate zones of North America, Europe and the FSU, the biomass potential is largest in the tropical regions of Africa, South America and Asia - although North America and the FSU have a significant potential too. Evidently, if interregional fuel trade is hampered by constraints, as in an A2 future, and technological innovations do not occur and spread, the WSB-potential will be significantly lower or even vanish in quite a few regions (Fig. 10).

Can electricity production from renewable resources in theory satisfy anticipated electricity demand? In Fig. 11, we present the ratio between the $<10 \notin \mathrm{kWh}^{-1}$ technical potential and the projected electricity demand in 2050 for the four scenarios. Globally, WSB potential is about 2 times higher than electricity demand under the A2 scenario and about 7 times higher than demand under the B1 scenario. Thus, theoretically, WSB potential is enough to meet global electricity demand. At the regional scale, there are marked differences. In many of the densely populated regions in the world, with consequently a high electricity demand per area, the WSB-potential cannot cover the total demand even theoretically. South East Asia and Japan can in all scenarios provide around $10 \%$ of regional electricity demand, but also in OECD, Eastern Europe and South Asia the potential is insufficient to meet demand if one were to include the intermittence of supply. ${ }^{21}$

\footnotetext{
${ }^{21} \mathrm{We}$ do not consider in this paper the constraints resulting from a mismatch between the supply patterns of wind and solar-PV and the load pattern in a particular region. Obviously, when these options penetrate significantly, there will be additional cost in the form of additional backup capacity, transport lines and storage equipment (see Hoogwijk et al., 2006). This is an area where more research and practical experience is urgently needed.
} 
For the other twelve regions the ratio of potential supply and expected demand remains above 1 in all scenarios. The highest ratios are found for the B1 scenario, due to the relatively lower electricity demand. The lowest ratios are found in A2, mainly explained by a relatively low WSB potential below $10 \varnothing \mathrm{kWh}^{-1}$ which is in turn caused by a high demand for agricultural land and low technology development. Some regions: Canada, Eastern Africa and Oceania, and to a lesser extent Western Africa and the FSU, have exceptionally high ratios due to a combination of a high potential and a low demand. These results suggest that, if the economic resources are available, the prospects for WSB-options for electricity supply within the region - in line with the A2/B2 future - are quite good to excellent in most of the less densely populated regions in the world.

\subsection{Sensitivity analysis}

From the previous analyses it will be clear that any estimation of the WSB potential has a large margin of uncertainty. Therefore, we add a one-factor sensitivity analyses for the A1 scenario to better understand the role of uncertainties. In Section 3.1, we have discussed uncertainties and selected some for the scenario construction. Previous estimates of WSB technical and economic
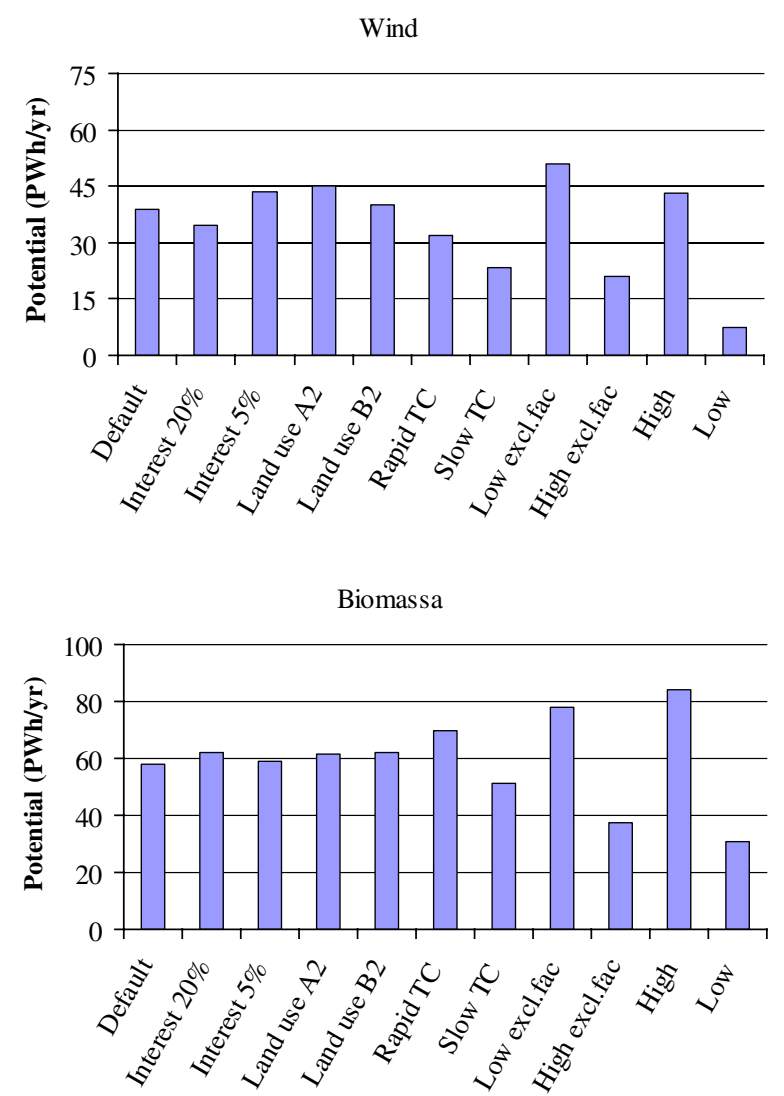

potentials turned out to be quite sensitive for assumptions on scenario-dependant class 2 parameters like conversion efficiencies and specific investment costs and interest rates (cf. Table 1). From the equations presented earlier, assumptions on land-use land cover change and suitability/availability are clearly important as well. Calculations show that for the low- and high-end values of the suitability/availability factor $f_{i}$ (cf. Table 2) the WSBoptions may have up to $50 \%$ less (wind) or $35 \%$ more (wind, biomass) economic potential - a difference of several times the present global electricity use in absolute terms. Nevertheless, as set out above, we have not included the $f_{i}$ in the scenario differentiation and therefore confine the sensitivity analysis now to the following parameters:

- Land cover: use A2 and B2 land-use patterns instead of default A1.

- Implementation fractions: $25 \%$ above and below the default value.

- Technology: use high and medium technology assumptions (cf. Table 3).

- Interest rate: variations between $5 \%$ and $20 \%$ around the default value.

Besides, we explored the full uncertainty range if all factors considered were varied within these ranges.
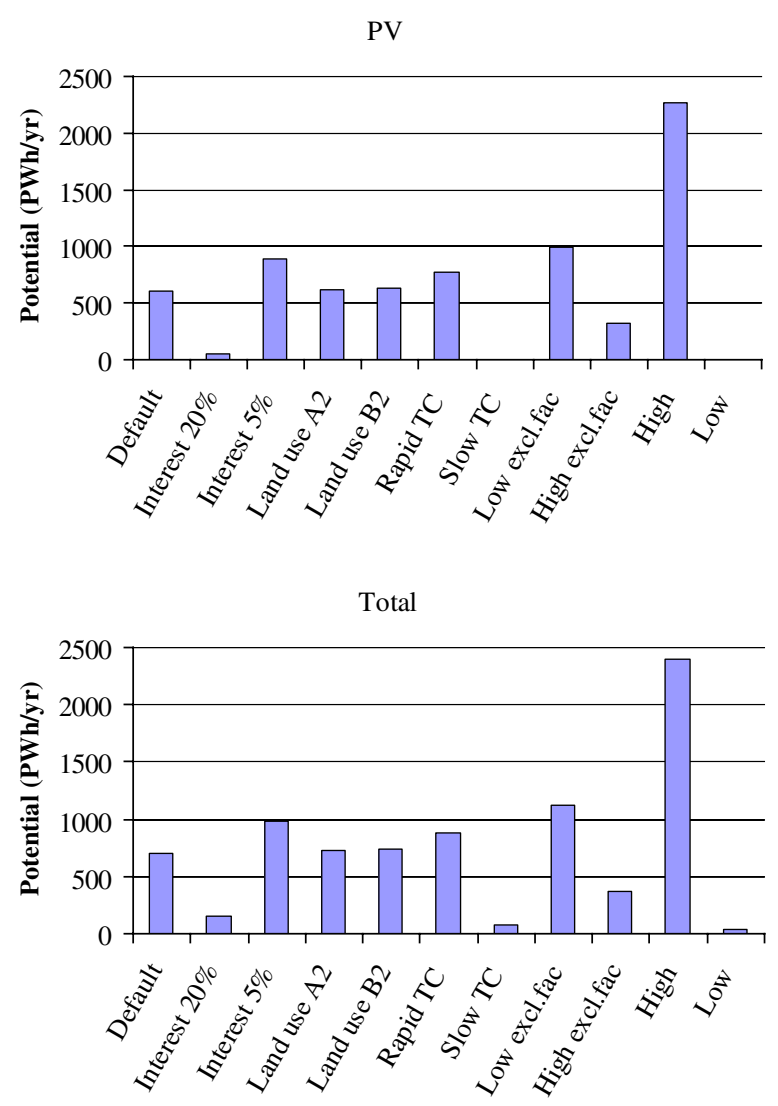

Fig. 12. Sensitivity analysis for the potential below $<0.1 \$ / \mathrm{kWh}$ based on default aggregation method for the A1 scenario in 2050 . Results show (1) interest (5\% and 20\%), (2) land-use pattern (A2 and B2 pattern), (3) technology assumptions (highest and lowest assumptions on the basis of Table 3), (4) the land-use implementation fraction $(50 \%$ higher and lower), (5) the impact of all factors (upper and lower range). 
The results (Fig. 12) show that wind remains in all cases an important contributor to the worldwide economic potential at less than $10 \varnothing \mathrm{kWh}^{-1}$, with a potential between 8 and $43 \mathrm{PWhyear}^{-1}$-or $50-300 \%$ of the 2000 world electricity demand. Electricity from biomass can be equally important, with a contribution of 30-85 $\mathrm{PWh}_{\text {year }}{ }^{-1}$. The availability of the land and the cost reduction from technological progress are the most influential. High exclusion rates for land reduce both the wind and biomass potential significantly. A lower rate of innovations also effects the potential, as it invalidates the Al standard assumption of rapid technology development. Changing land-use patterns due to different economic and population growth (A2/B2) causes only minor changes. The impact of the interest rate is also small, because in the range considered wind generation costs remain below the cutoff cost of $10 \notin \mathrm{kWh}^{-1}$.

The largest potential contribution is from solar-PV but its economic potential $\left(<10 \notin \mathrm{kWh}^{-1}\right)$ is very sensitive to the cost determinants, as discussed before (cf. Fig. 6). When the technological breakthroughs are not happening, a large part of the huge potential will never cross this cutoff cost boundary and even bring it below those of wind and biomass. Its capital-intensive nature makes it also sensitive for changes in the interest rate, for the same reason. High or low exclusion factors also effect the solarPV potential, but land does not seem to be the constraint here: even with the high exclusion factor the potential is over 20 times the 2000 world electricity demand (Fig. 12).

\section{Renewable energy outlook: implementation potential}

Elsewhere we have compared our results with previous studies by others (Hoogwijk, 2004; Hoogwijk et al., 2005). In Table 5, we compare our results to the figures presented in the World Energy Assessment (World Energy Assessment (WEA), 2000) and to estimates of the implementation potential (period 2020-2030) in some recent scenarios. What do these potentials say about the possible and probable future of renewable energy in regional and world energy systems? First, it has to be realized that a proper assessment of the role of WSB in the regional/world energy system requires the implementation of the supply cost curves into an integrated assessment (energy and land-use land cover) model such as IMAGE/TIMER in order to get an idea of over-all system costs (De Vries et al., 2000, 2001; Palmer and Burtraw, 2005). Here, again, there are major uncertainties which will influence the technical and economic and in particular the implementation potential. What will be the costs of the alternative competing energy supply and land-use options, what is the future energy demand, which are the costs of system expansion in order to guarantee reliability, how will fuel trade influence competitiveness, how does public perception of WSB and alternatives such as nuclear energy influence the penetration rate? Such questions may actually dominate the WSB- potential in some situations. ${ }^{22}$ Taking this 'renewable energy environment' into account implies a dynamic scenario for such variables as land use for food, cost/price development of other energy carriers and the prevailing value orientations and risk attitudes of people. This will be pursued in a subsequent paper.

There are at least three forces that will to a large extent determine the realisation of any WSB-potential:

- energy supply security, in particular oil and gas: rising demand and depletion will contribute to economic, political and social instabilities, a.o. in the form of rising and fluctuating prices;

- environmental impacts, notably climate change: fossil fuel combustion is a major culprit and less and/or clean use of fossil fuels (mitigation) is needed besides adaptation;

- socio-economic considerations: half of the world population still lives in rural areas and for them considerations of local employment and autonomy as well as development and introduction of decentralised options may be of paramount concern besides cost-per-se.

All three may help to overcome the existing gap in generation costs. Rising fossil fuel costs, the need to install carbon capture and storage (CCS) on coal-fired plants and controversies about large-scale use of nuclear power will tend to advantage WSB - but counteracting forces will come into play such as the resistance against land-use impacts (noise, visual, etc.-NIMBY).

The actual penetration dynamics of WSB will depend on the interplay of these forces which can be woven into the previously discussed scenario narratives. In the OECDregion most governments and (big) business consider the energy security issue the most challenging and important one. Much RD\&D-effort is directed to this issue. Environmental risks are a second or at times, after an alarmingly hot summer or fierce storm, first priority. It has led, notably in the EU, to a set of ambitious targets for WSB sources, which seem to fit best in a B1-scenario. Job security is from an industrial point-of-view not really important in this capital-intensive sector, but providing alternative income opportunities for farmers or a genuine desire for local/regional autonomy in rural Europe or Indian and African villages may become decisive considerations in some situations, which would explicitly fit in a B2-future.

What does this mean for energy policy? A variety of policies has been implemented to stimulate the development and penetration of WSB options. Many countries

\footnotetext{
${ }^{22}$ For instance in the UK where Scottish electricity producers plan to sell $2000 \mathrm{MWe}$ windpower to the more profitable market in the south, which would require $€ 730 \mathrm{mln}$ to upgrade the existing network. Similarly, development of the Mid-West USA potential would necessitate major transport investments as they are far from the big load centers - a 'wind pipeline' of $10-20$ billion $\$$ for $>10 \mathrm{GWe}$ transport capacity has been proposed (www.windpower-monthly.com).
} 
Table 5

Comparison of the long-term technical potential of WSB-options as reported in the World Energy Assessment (WEA, 2000), this study and some recent scenarios

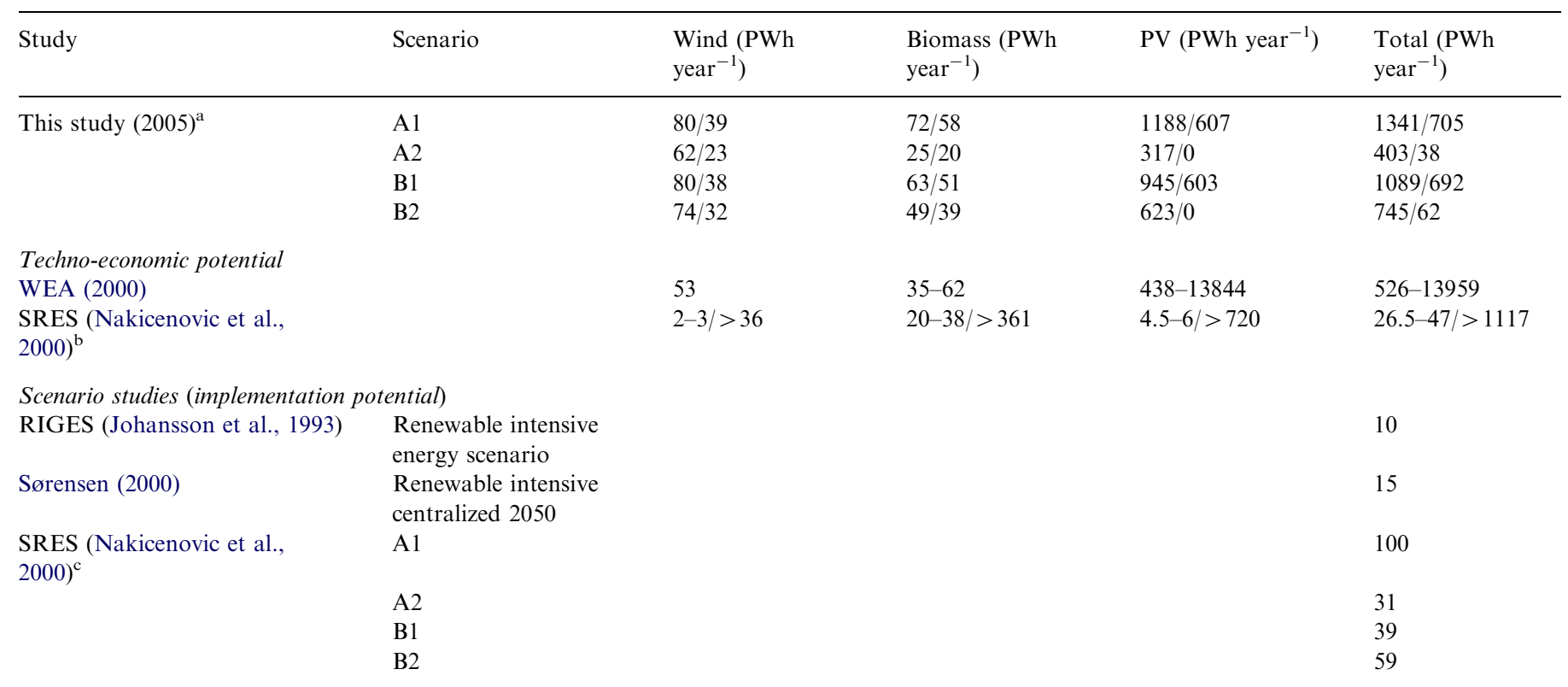

\footnotetext{
${ }^{\mathrm{a}}$ Shown are technical potential and economic potential at production costs $<10 \varnothing \mathrm{kWh}^{-1}$.

${ }^{\mathrm{b}}$ Shown are potential by $2020-2025$ and long-term technical potential.

${ }^{\mathrm{c}}$ Includes both fuel and electricity.
}

(at least 48) have some kind of renewable energy policy and have introduced renewable energy targets, usually in the range of $5-30 \%$ of total electricity use within the next 10-20 years (REN21, 2005). A variety of rules and regulations is being attempted: direct financial transfers (subsidies, RD\&D), preferential tax treatments (e.g. biodiesel), trade restrictions, energy-related services by governments at less than full cost (including infrastructure and public $\mathrm{R} \& \mathrm{D}$ ), regulation of the energy sector and imposition of external costs ('negative subsidy'). Most countries and states use the feed-in policy and renewable portfolio standards, but direct investment subsidies are also used often (REN21，2005). Yet, only 7\% of energy subsidies in the EU-15 2001-budget and only $18 \%$ of the on- and off-budget energy subsidies of 29.2 billion $€$ in 2001 in the EU-15 went to renewable energy (www.eea.eu.int). This fraction has been rising slowly, at the expense of fossil fuel and nuclear subsidies, and this could be accelerated considerably if a stringent climate policy is coming off the ground with a permanent and rising carbon tax on all forms of energy.

\section{Discussion and conclusions}

In this paper, we have presented the results of an integrated assessment of the potential to produce electricity from wind, solar-PV and biomass (WSB) and liquid fuel from biomass. Unlike most earlier assessments, a welldefined methodology was used to estimate the potential of these renewables - making the results comparable across different types of renewables and regions and over time. We conclude from our analysis that:

- Assessment of the future potential for renewable power at different cost levels should be done using an explicit scenario context: Many parameters in geographic and techno-economic estimates of renewable energy potentials are uncertain and dependent on broader developments such as future land use. Scenario-based assessment can provides some consistency ('logic') in assumptions and thus communicate the broad range of outcomes resulting from divergent pathways for e.g. land use and technology.

- Competition for land between the WSB options may significantly effect their potential to produce electricity: The WSB options will, to some degree, use the same land types to produce electricity, i.e. abandoned agricultural land and grass-type natural ecosystem. Therefore, it is not possible to determine the combined potential by simply adding up the individual potentials. Interaction effects could reduce the WSB-potentials with up to $70 \%$.

- Besides, there are other important uncertainties, coming in particular from the assumptions on the suitability/ availability of land and on technology-induced cost reductions: If much land turns out to be unavailable e.g. due to people's resistance, or if technological breakthroughs do not occur, the WSB-potential could be reduced with a factor $5-10$. 
More specific conclusions are:

- The potential to produce liquid biofuels from primary biomass exceeds the potential transport fuel demand in 3 out of 4 scenarios: Under the 4 scenarios analysed, the potential to produce liquid biofuels from biomass varies between 80 and $300 \mathrm{EJ} \mathrm{year}^{-1}$ in 2050, the range coming from both different land-use patterns and different assumptions on technology development. This would suffice to supply an estimated worldwide transport fuel demand of 180-250 EJ year ${ }^{-1}$.

- Wind power seems to be the most interesting of the WSB option to produce electricity: In most scenarios, wind power is able to produce electricity at somewhat lower costs in 2050 than biomass - up to $0.04 \$ \mathrm{kWh}^{-1}$. The potential of power from wind and biomass below 0.10 \$ $\mathrm{kWh}^{-1}$ ranges from 20 to $80 \mathrm{PWh}_{\text {year }}{ }^{-1}$. Solar-PV costs are higher, at the cheapest sites costs may be just below $0.10 \$ \mathrm{kWh}^{-1}$; its technical potential, however, is much higher than of the other options.

- Whether solar-PV becomes available at costs below $10 \notin \mathrm{kWh}^{-1}$ depends largely on the assumed technological development. Our results showed that in the more technology development conservative scenario A2, in 2050 the costs of centralised solar-PV have still not reach $10 \notin \mathrm{kWh}^{-1}$. Nevertheless, solar-PV may be increasingly competitive in some small niche markets.

- The combined potential of the WSB options can in most regions supply future electricity demand at costs below $0.10 \$ \mathrm{kWh}^{-1}$ : Regions with a high WSB potential over electricity demand ratio include Canada (mainly wind), the African regions (solar-PV and wind), FSU (wind and biomass), Middle East (solar-PV) and Oceania (all sources). In other region, WSB supply is significantly lower than electricity demand (South East Asia and Japan). Ratios around one are found for OECD Europe, Eastern Europe and South Asia.

It should be borne in mind that our evaluation has some limitations, which also indicate directions for further research. First, our data on wind speed, solar irradiation and land characteristics are rather coarse and this may, besides not permitting sitespecific judgments, bias the regional estimates. Comparison with local studies can make the results more robust. Secondly, we did not consider the additional system costs occurring at high $(>15 \%)$ wind and solar-PV and penetration, for instance for back-up capacity and the cost of discarded electricity in moments of supply-demand mismatch. To assess these costs, electricity system simulation is required (see e.g. Grubb and Meyer, 1993; Fellows, 2000; Hoogwijk et al., 2006). Thirdly, quite some assumptions are rather arbitrary, given the difficulty of forecasting long-term societal and technological dynamics. We have used the scenario approach to deal with this problem, but further elaboration of the storylines will provide more insight into uncertain parameters such as the land availability.

\section{Appendix A. Basic equations to calculate ESB-potentials}

In this appendix, the equations for the calculation of the potentials for biomass, wind and solar-PV are given, as specifications of the more general formulations in section.

\section{A.1. Liquid transport fuel and electricity from biomass} (Section 2.3)

The geographical potential of biomass from energy crops becomes for a grid-cell $i$ (cf. Eq. (1)):

$E G_{i}=\sum_{i=1}^{n} f_{i} A_{i} Y_{i} M F \quad\left(\mathrm{GJ}\right.$ grid-cell $\left.{ }^{-1}\right)$

with the suitability/availability factor $f_{i}$ accounting for competing land-use options, $Y_{i}$ the harvested rainfed yield of energy crops in grid cell $i$ based on IMAGE 2.2 $\left(\mathrm{GJ} \mathrm{m}^{-1}\right.$ year $\left.{ }^{-1}\right)$, and MF the management factor representing the development of management and technology $(-)$.The economic potential is derived from the cost of primary biomass $C_{\text {prim }, i}$, calculated for grid-cell $i$ as

$C_{\text {prim }, i}=C L_{i \subset R} / Y_{i}+a \lambda_{\text {Bprim }} K_{\text {Bprim }}+w \lambda_{p} L \quad\left(\$ \mathrm{GJ}^{-1}\right)$

with $C L_{i<R}$ the region-dependant land costs $\left(\$ h a^{-1}\right)$ taken from Hoogwijk (2004), $a$ the annuity factor $\left(\mathrm{y}^{-1}\right)$, $\lambda_{\text {Bprim }}$ the learning coefficient and $K_{\text {Bprim }}, L$ the specific capital $\left(\$ \mathrm{GJ}^{-1}\right.$ year $\left.^{-1}\right)$ and labour $\left(\mathrm{h} \mathrm{GJ}^{-1}\right)$ requirements, respectively. The conversion of primary biomass into liquid biofuel or feedstock for electricity production is calculated as

$C_{s e c, i}=C P_{i} / \eta+a I_{B \sec } \lambda_{B s e c} / L F_{s}+O M_{s} \lambda_{B \text { sec }} \quad\left(\$ G^{-1}\right)$

with $\eta$ the conversion efficiency, $I_{B s e c}$ the specific investment costs, $\lambda_{B s e c}$ the learning factor, $L F_{s}$ the load factor (h year ${ }^{-1}$ ) and $O M_{s}$ the operation and maintenance costs $\left(\$ \mathrm{GJ}^{-1}\right)$ for the conversion equipment under consideration. The expression for the resulting electricity generation cost is

$C_{\text {Belec }, i}=C_{\mathrm{sec}, i} / \eta+a I / L F_{\text {elec }}+O M_{\text {elec }} \quad\left(\$ \mathrm{GJ} \mathrm{e}^{-1}\right)$.

\section{A.2. Electricity from on-shore wind (Section 2.4)}

The function used to convert windspeed data at grid-cell level into the geographical/technical potential (cf. Eqs. (1) and (2)) can be written in condensed form as

$$
E T_{i}=\left[\left(A_{i}-u_{i}\right) a_{i} w_{i} b_{i} r_{i} / A_{i}\right] A_{i} \eta_{a} \eta_{a r} D h_{f, i} \quad\left(\mathrm{~W} \text { grid-cell }^{-1}\right)
$$


with the first term between brackets the suitability/ availability factor $f_{i}$ in the area $A_{i}$.

The parameter $r_{i}$ indicates whether the wind regime in grid-cell $i$ is viable, i.e. the adjusted average wind speed should exceed $4 \mathrm{~m} \mathrm{~s}^{-1}$ at a height of $10 \mathrm{~m}$, leading to regional $r$-values in the range of 0.01 (Southern Africa) to 0.55 (USA). The parameter $u_{i}$ is urban land (excluded), $a_{i}$ land above $2000 \mathrm{~m}$ (excluded), $w_{i}$ land use such as agriculture and $b i$ bioreserves (partly excluded). $\eta_{a}$, is the average availability of the wind turbine $(-)$, set at a conservative 0.95. $\eta_{a r}$ is the wind farm array efficiency (-), set at 0.9 , which reflects the configuration of windturbines in a farm and is equivalent with the placing of four $1 \mathrm{MW}$ turbines $500 \mathrm{~m}$ apart. $D_{i}$ is the power density $\left(\mathrm{MW} \mathrm{km}^{-2}\right)$ and $h_{f, i}$ indicates the full-load hours the average windturbine in this area is assumed to operate (h).

Appendix B. Main input parameters for the four scenarios

\section{A.3. Electricity from solar-PV (Section 2.5)}

The conversion from solar irradiance data at grid-cell level into the technical potential is similar to the one for wind energy (cf. Eq. (A.5)):

$E T_{i}=\left[f_{i} A_{i}\right] 8760 I_{i} \quad\left(\right.$ Wh grid-cell $\left.{ }^{-1}\right)$

with $I_{i}$ the annually averaged irradiance in cell $i\left(\mathrm{~W} \mathrm{~m}^{-2}\right)$ and $8760 \mathrm{~h}$ in a year. The first term between brackets equals the product of suitability/availability factor $f_{i}$ and cell area $A_{i}$ and indicates the area considered suitable for solar-PV. The orientation of the installed PV modules towards the sun is important for the output; we have assumed horizontally placed modules.

\begin{tabular}{|c|c|c|c|c|c|c|}
\hline & 2000 & $\begin{array}{l}\text { A1 } \\
2050\end{array}$ & $\begin{array}{l}\text { A2 } \\
2050\end{array}$ & $\begin{array}{l}\text { B1 } \\
2050\end{array}$ & $\begin{array}{l}\text { B2 } \\
2050\end{array}$ & Unit \\
\hline \multicolumn{7}{|l|}{ Wind } \\
\hline Conversion efficiency & 0.91 & 0.99 & 0.9 & 0.99 & 0.95 & - \\
\hline Array efficiency & 0.9 & 0.97 & 0.9 & 0.97 & 0.95 & - \\
\hline Spec investment costs ${ }^{\mathrm{a}}$ & 935 & & & & & $\$ \mathrm{~kW}^{-1}$ \\
\hline System lifetime & 20 & 30 & 30 & 30 & 30 & year \\
\hline Full load maximum hours & 4000 & 5000 & 4500 & 5000 & 4750 & hours \\
\hline Nominal power & 1100 & 2700 & 1450 & 2700 & 2000 & MW \\
\hline \multicolumn{7}{|l|}{ Solar-PV } \\
\hline Conversion efficiency & 0.14 & 0.3 & 0.2 & 0.3 & 0.25 & - \\
\hline Performance ratio & 0.8 & 0.95 & 0.75 & 0.95 & 0.95 & - \\
\hline Module investment costs & 3 & 0.75 & 1.75 & 0.75 & 1 & $\$ \mathrm{WP}^{-1}$ \\
\hline BOS investment costs & 3 & 0.6 & 1.75 & 0.6 & 1 & $\$ \mathrm{WP}^{-1}$ \\
\hline System lifetime & 25 & 30 & 30 & 30 & 30 & year \\
\hline \multicolumn{7}{|l|}{ Biomass elec } \\
\hline Elec conversion efficiency & 0.38 & 0.53 & 0.49 & 0.53 & 0.51 & $\%$ \\
\hline Spec investment costs & 1400 & 1050 & 1225 & 1050 & 1110 & \$/MW \\
\hline BSF Spec invest costs $(1970=1)$ & 0.9 & 0.53 & 0.81 & 0.53 & 0.63 & - \\
\hline MF woody & 0.5 & 1.25 & 1.05 & 1.15 & 1.10 & - \\
\hline \multicolumn{7}{|l|}{ Biomass liquid } \\
\hline BLF Spec invest costs $(1970=1)$ & 0.87 & 0.56 & 0.73 & 0.56 & 0.66 & - \\
\hline MF sugar & 0.75 & 1.5 & 1.23 & 1.38 & 1.23 & - \\
\hline Conversion efficiency (woody) & 0.45 & 0.55 & 0.50 & 0.55 & 0.50 & - \\
\hline Conversion efficiency (sugar) & 0.40 & 0.53 & 0.47 & 0.53 & 0.47 & - \\
\hline \multicolumn{7}{|l|}{ General } \\
\hline Interest rate & 0.1 & 0.1 & 0.1 & 0.1 & 0.1 & year $^{-1}$ \\
\hline $\mathrm{O} \& \mathrm{M}$ costs & 3 & 3 & 3 & 3 & 3 & $\%$ of investment I \\
\hline
\end{tabular}

BLF BioLiquidFuel BSF BioSolidFuel MF ManagementFactor

${ }^{\mathrm{a}}$ The specific investment costs of $935 \$ \mathrm{~kW}^{-1}$ for the starting year is derived from an average $1000 \$ \mathrm{~kW}^{-1}$ for $800 \mathrm{~kW}$ turbines and a scaling coefficient of -0.3 . 


\section{References}

Abed, K.A., El-Mallah, A.A., 1997. Capacity factor of wind turbines. Energy 22 (5), 487-491.

Alcamo, J., Leemans, R., Kreileman, E. (Eds.), 1998. Global Change Scenarios of the 21st Century-Results From the Image 2.1 Model. Elsevier, Oxford.

Alcamo, J., Mayerhofer, P., Guardans, R., van Harmelen, T., van Minnen, J., Onigkeit, J., Posch, M., de Vries, B., 2002. An integrated assessment of regional air pollution and climate change in Europe: findings of the AIRCLIM project. Environmental Science and Policy 5, 257-272.

ATLAS, 2005. Historical and future costs of electricity produced by renewable energy technologies. 〈http://europe.eu.int/comm/energy_transport/atlas/homeu.html $>$.

Berndes, G., Hoogwijk, M., van den Broek, R., 2003. The contribution of biomass in the future global energy supply: a review of 17 studies. Biomass and Bioenergy 25 (1), 1-27.

Brink, B.J.E., et al., 2006. Cross-roads of Planet Earth's Life: Exploring means to meet the 2010-biodiversity target. MNP Bilthoven, The Netherlands.

British Wind Energy Association (BWEA), 2000. Planning for wind energy - A guide for regional targets. London.

Cabooter, Y., Dewilde, L., Langie, M., 1999. An Inventory of Locations Suitable for Wind Energy in Flanders Regions. European Wind Energy Conference, Nice.

Damen, K., Faaij, A., 2004. A life cycle inventory of existing biomass import chains for "green" electricity production. Mitigation and Adaptation Strategies for Global Change 11 (5-6), 1023-1050.

De Vries, B.J.M, 2006. Scenarios: guidance for an uncertain and complex world? In: Costanza, R., Graumlich, L., Steffen, W. (Eds.), Integrated History and Future Of People on Earth (IHOPE). Proceedings 96th Dahlem Workshop. MIT Press, Cambridge, Mass.

De Vries, B., Bollen, J., Bouwman, L., den Elzen, M., Janssen, M., Kreileman, E., 2000. Greenhouse-gas emissions in an equity-, environment- and serviceoriented world: an IMAGE-based scenario for the next century. Technological Forecasting and Social Change 63 (2-3).

De Vries, H.J.M., van Vuuren, D.P., den Elzen, M.G.J., Janssen, M.A., 2001. The Targets Image Energy Model Regional (TIMER) Technical Documentation. National Institute of Public Health and the Environment (RIVM), Bilthoven, The Netherlands.

Energy Information Agency (EIA), 1999. Assumptions to the annual energy outlook 1999-renewable fuels module. Washington, D.C.

Elliot, D.L., Schwartz, M.N., 1993. Wind Energy Potential in the United States. Pacific Northwest Laboratory.

Ericsson, K., Nillson, L.J., 2004. International biofuel trade - a study of the Swedish import. Biomass and Bioenergy 26 (3), 205-220.

EWEA/Greenpeace, 2002. Windforce 12, A blueprint to achieve $12 \%$ of the world's electricity from wind power by 2020. EWEA/Greenpeace.

Fellows, A., 2000. The Potential of Wind Energy to Reduce Carbon Dioxide Emissions. Garrad Hassan, Glasgow.

Grubb, M.J., Meyer, N.I., 1993. Wind energy: resources, systems, and regional strategies. In: Johansson, T.B., Kelly, H., Reddy, A.K.N., Williams, R.H. (Eds.), Renewable Energy: Sources for Fuels and Electricity. Island Press, Washington, DC.

Hall, D.O., Rosillo-Calle, F., Williams, R.H., Woods, J., 1993. Biomass for energy: supply prospects. In: Johansson, T.B., Kelly, H., Reddy, A.K.N., Williams, R.H. (Eds.), Renewable Energy-Sources for Fuels and Electricity. Island Press, Washington, DC.

Hamelinck, C., 2004. Outlook for Advanced Biofuels. Science, Technology and Society. Utrecht University.

Harmon, C., 2000. Experience Curves of Photovoltaic Technology. IIASA, Luxemburg.

Hendriks, C., Harmelink, M., Burges, K., Ransel, K., 2004. Power and Heat Productions: Plant Developments and Grid Losses. Ecofys, Utrecht.

Hofman, Y., de Jager, D., Molenbroek, E., Schilig, F., Voogt, M., 2002. The Potential of Solar Electricity to Reduce $\mathrm{CO}_{2}$ Emissions. Ecofys, Utrecht.
Hoogwijk, M., 2004. On the global and regional potential of renewable energy sources. Utrecht University 〈http://www.library.uu.nl/ digiarchief/dip/diss/2004-0309-123617/full.pdf $\rangle$.

Hoogwijk, M., de Vries, H.J.M., Turkenburg, W.C., 2004. Assessment of the global and regional geographical, technical and economic potential of onshore wind energy. Energy Economics 26, 889-919.

Hoogwijk, M., Faaij, A., Eickhout, B., de Vries, B., Turkenburg, W., 2005. Potential of biomass energy out to 2100 , for four IPCC SRES land-use scenarios. Biomass and Bioenergy 29, 225-257.

Hoogwijk, M., van Vuuren, D., de Vries, H.J.M., Turkenburg, W.C., 2006. Exploring the impact on cost and electricity production of high penetration levels of intermittent electricity on OECD Europe and the USA. Accepted for publication in Energy.

IEA (International Energy Agency), 2000. Experience Curves for Energy Technology Policy. (C.-O. Wene). IEA, Paris.

IMAGE-team, 2001. The IMAGE 2.2 Implementation of the SRES Scenarios. A Comprehensive Analysis of Emissions, Climate Change and Impacts in the 21st Century. National Institute for Public Health and the Environment (RIVM), Bilthoven, The Netherlands.

Johansson, T.B., Kelly, H., Reddy, A.K.N., Williams, R.H. (Eds.), 1993. Renewable Energy: Sources for Fuels and Electricity. Island Press, Washington, DC

Junginger, M., Faaij, A., Turkenburg, W., 2005. Global experience curves for wind farms. Energy Policy 33, 133-150.

Kobos, P.H., Erickson, J.D., Drennen, T.E., 2005. Technological learning and renewable energy costs; implications for US renewable energy policy. Energy Policy 34 (13), 1645-1658.

Loveland, T.R., Belward, A.S., 1997. The IGBP-DIS global $1 \mathrm{~km}$ cover data set discover. First results. International Journal of Remote Sensing 18, 3289-3295.

Nakicenovic, N., Alcamo, J., Davis, G., de Vries, B., Fenhann, J., et al., 2000. Special Report on Emissions Scenarios (SRES). Cambridge University Press, Cambridge, UK.

Nemet, G.F., 2005. Beyond the learning curve: factors influencing cost reductions in photovoltaics. Energy Policy 34 (17), 3218-3232.

New, M., Hulme, M., Jones, P., 1997. A 1961-1990 Mean Monthly Climatology of Global Land Areas. Climate Research Unit, Norwich.

New, M., Hulme, M., Jones, P., 1999. Representing Twentieth Century Space-Time Climate Variability, Part I: Development of a 1961-91 Mean Monthly Terrestrial Climatology. American Meteorological Society, Providence, RI. March, pp. 820-856.

Palmer, K., Burtraw, D., 2005. Cost-effectiveness of renewable electricity policies. Energy Economics 27 (6), 873-894.

REN21, 2005. Renewables 2005 Global Status Report. Worldwatch Institute, Renewable Energy Policy Network, Washington, DC.

Rogner, H.H., 2000. Energy resourcesand technology options (Ch. 5). In: World Energy Assessment (WEA). UNDP, New York.

Solarbuzz, 2002. SolarBuzz module prices. 〈www.solarbuzz.com〉.

Sørensen, B., 2000. Renewable Energy, second ed. Academic Press, New York.

Strengers, B.J., Leemans, R., Eickhout, B., de Vries, B., Bouwman, A.F., 2004. The land use projections in the IPCC SRES scenarios as simulated by the IMAGE 2.2 model. GeoJournal 61, 381-393.

Turkenburg, W.C., 2000. Renewable energy technologies. In: Goldemberg, J. (Ed.), World Energy Assessment. UNDP, Washington, DC.

WEA (World Energy Assessment), 2000. Energy and the Challenge of Sustainability. UNDP-United Nations Development Programme, New York.

Weingart, J.M., 1978. The Helios strategy: an heretical view of the potential role of solar energy in the future of a small planet. Technological Forecasting and Social Change 12, 273-315.

German Advisory Council on Global Change (WBGU), 1999. World in transition - conservation and sustainable use of the biosphere. Berlin (http://www.wbgu.de/wbgu_sn1999_engl.pdf).

World Commission on Protected Areas (WCPA), 2000. Protected Areas: Benefits Beyond Boundaries - WCPA in Action. IUCN/WPCA, Gland.

World Energy Council (WEC), 1994. New Renewable Energy Resources-A Guide to the Future. Kogan Page Limited, London. 